\title{
Large-Scale Circulations over East Asia during Baiu Period of 1979
}

\author{
By K. Ninomiya \\ Numerical Prediction Division, Japan Meteorological Agency, Tokyo 100 \\ and $\mathrm{H}$. Muraki \\ Tokyo District Meteorological Observatory, Tokyo 100 \\ (Manuscript received 3 February 1986, in revised form 31 March 1986)
}

\begin{abstract}
Large-scale situation over East Asia during the Baiu period of 1979 was studied on the basis of 10-day averaged fields.

The development of warm ridge over the Mongol Sibirsk Plateaus (Baiu ridge) and cold trough elongated from the Bering Sea cyclone to China (Baiu trough) were the major systems in Baiu season in middle $\sim$ high latitudes. With the rapid temperature rise over the Continent and the slow temperature rise over the Pacific north of $\sim 35^{\circ} \mathrm{N}$, the large temperature difference between the Continent and the Pacific was maintained. The circulations in the lower troposphere in the Baiu season were characterized by the northerly wind in the west side of the Baiu trough (Baiu-trough-northerly), the southerly wind over the South China Sea, low-level-jet like strong WSW wind along the northern periphery of the Pacific anticyclone, and the Indian monsoon westerly wind.

While the Meiyu front was related with a shear line between the South China Sea southerly and the Baiu-trough-northerly wind (Baiu shear line), the Baiu front was located $\sim 1500 \mathrm{~km}$ south of the Baiu trough and associated with convergence/confluence of SW wind to the strong WSW wind zone. Another feature of interest is the difference between the structure of the Meiyu and the Baiu fronts.

The northward advance of the Pacific anticyclone and the Baiu front is the basic seasonal change. The quasi-periodic ( $\sim 40$-day period) intraseasonal variations of the Pacific anticyclone and the Baiu front were superposed upon this seasonal change. The intraseasonal variations of the Baiu front were related to the activity of ITCZ in the South China Sea as well as the variations of the monsoon precipitation.

From the analysis, the role of the Tibetan Plateau, the Baiu-trough-northerly wind, cold advection associated with the Bering Sea cyclone over the cold northwestern Pacific in maintaining the Baiu/Meiyu front was inferred. This inference was supported by the results of prediction experiment by Nakamura, Hasegawa and Ninomiya (1985).
\end{abstract}

\section{Introduction}

June and July are the rain season over East Asia. A quasistationary front extends along $30 \sim 40^{\circ} \mathrm{N}$ over China (Meiyu front) and Japan (Baiu front). A cloud/precipitation zone associated with the front extends from South China to Japan and farther to the Pacific.

Many observational studies and a few numerical simulations on the Baiu front and Baiu frontal disturbances (e.g., Akiyama, 1973, 1978, 1984; Matsumoto et al., 1970, 1971; Muraki,
1985; Ninomiya, 1978, 1980, 1984; Ninomiya and Akiyama, 1971; Ninomiya and Yamazaki, 1979; Ninomiya et al., 1981, 1984; Yoshizumi, 1977) have shown the following features:

(1) The Baiu front is located along the northern boundary of tropical maritime airmass. The structure of the Baiu front is different from that of the polar front, which is located around $60^{\circ} \mathrm{N}$ in June and July.

(2) The Baiu front is associated with the low-level-jet like strong WSW winds in 900 $700 \mathrm{mb}$, large moisture gradient and thick moist 
neutral (low $\mathrm{Ri}$ number) layer. The thermal gradient in the frontal zone is weak over the area to the west of $135^{\circ} \mathrm{E}$.

(3) Medium-scale (meso- $\alpha$-scale) frontal depressions develope along the Baiu front.

(4) Intense Baiu precipitation is produced by successive development of these depressions. In many cases, the precipitation system of a medium-scale depression is composed of a few meso- $\beta$-scale precipitation systems.

(5) The frontogenesis, generation of convective instability and the strong moisture convergence in the Baiu frontal zone are due to the confluence/convergence of SW flow along the northwestern periphery of the Pacific anticyclone to the zone of strong WSW wind.

The Japanese authors cited above paid attention mainly on the Baiu front and the circulations in the subtropical latitudes, without considering the situations in the middle and high latitudes.

On the one hand, several studies on the Meiyu front (e.g., Chen and Chang, 1980; Lau and Li, 1984) showed its association with the Meiyu trough (a trough in the lower troposphere extending from the Japan Sea to central China). Saito (1985) also pointed out that the Baiu front is located to the southeast of a $500 \mathrm{mb}$ trough extending from the north Pacific to central China. Matsumoto (1985) analyzed the $850 \mathrm{mb}$ wind field in relation to the frontal zone over East Asia in summer.

Recently several authors studied features of large-scale circulations over East Asia during the summer of 1979. Murakami and Ding (1982) described changes in wind and temperature fields over Eurasia in the early summer. An abrupt increase of $300 \mathrm{mb}$ temperature and intensification of $300 \mathrm{mb}$ anticyclone were seen around 5 June in association with the onset of rain season over China and Japan and $\sim 15$ days prior to the onset of Indian monsoon. The northward shift of $300 \mathrm{mb}$ jet stream from 30 to $40^{\circ} \mathrm{N}$ and rapid establishment of $700 \mathrm{mb}$ easterly around $25^{\circ} \mathrm{N}$ were observed over India. However the northward shift of the $300 \mathrm{mb}$ jet stream was not seen over the eastern Tibetan Plateau.

Luo and Yanai (1983) described the oro- graphic and thermal influences of the Tibetan Plateau upon the low-level wind field in the early summer. The areas of organized precipitations were related to the quasi-stationary BurmaIndia trough, Meiyu front and transverse trough extending eastward from the Plateau.

Murakami and Huang (1984) studied the nature of disturbances which brought the Meiyu rainfalls over China for 1 May 15 June (Period 1) and 16 June $\sim 31$ July 1979 (Period 2). They described the birthplace and evolution process of the Period 1 and 2 cyclones.

Kato (1985) studied the abrupt change in the structure of Meiyu front over China in late May, which was characterized by decrease of temperature gradient in Meiyu front and the increase of convective instability.

Murakami, M. (1984 and 1985) described the northward advance of the convective area over the southeastern Asia, the formation of highly convective zone of Meiyu-Baiu front and the northward shift of ITCZ over the western Pacific in May August 1979 using IR data of the geostationary satellite. Intraseasonal variations with a $\sim 40$-day period in convective activity and wind field related with active/break cycle of the Indian monsoon were also pointed out. Similar analysis was also made by Krishinamurti and Subrahmanyam (1982).

Nevertheless, the relation between the Baiu and Meiyu front, the influence of the middle and high latitude circulations on the Baiu/Meiyu front have not been fully studied yet. In the present paper, the authors study the large-scale features over East Asia for May August 1979 by analyzing 10-day averaged fields. We pay special attention on the following problems;

(1) Comparison of the Baiu front with the Meiyu front.

(2) Large-scale circulations in the middle and high latitudes related with Baiu/Meiyu precipitations.

(3) Variation of the Pacific anticyclone in relation with that of the Baiu front.

(4) Seasonal change in the large-scale fields associated with the onset and withdrawal of the Baiu/Meiyu season.

The following data are used in the present study: 
(1) Data of northern hemisphere objective analysis of JMA at $381 \mathrm{~km}$ grid points.

(2) Precipitation data at surface stations.

(3) Amount of high-cloud (higher than 400 $\mathrm{mb}$ level) estimated from IR observation from GMS (Geostationary Meteorological Satellite).

\section{Baiu and Meiyu precipitation in 1979}

Fig. 1 presents the time-series of daily precipitation averaged over each of 9 areas in the map on the upper-left part of Fig. 1. Over Japan, data on the stations indicated by blacked circle were used to calculate the area-averaged precipitation. The data on China were obtained from Murakami and Huang (1984).

\section{Precipitation over Japan}

Prior to the Baiu period, a few peaks of intense precipitation occurred in $1 \sim 15$ May over $27.5 \sim 37.5^{\circ} \mathrm{N}$ zone. Synoptic analysis indicated that these precipitations were associated with synoptic-scale cyclones and not the
Baiu precipitation. Alternate spells of fine weather and weak precipitation were seen in $15 \sim 30$ May over $27.5 \sim 37.5^{\circ} \mathrm{N}$ zone.

The Baiu precipitation in area $\mathrm{JW}_{25}$ began around 20 May while that in the northern areas around 5 June. The precipitation was specially intense over southwestern Japan ( $\mathrm{JW}_{30}$ and $\mathrm{JW}_{35}$ ) for 15 June $\sim 20$ July. The peak value of area-averaged precipitation reached to $\sim 70$ $\mathrm{mm} /$ day. The Baiu precipitation in $\mathrm{JW}_{25}$ and the northern zones ended around 20 June and 20 July respectively. No significant break of rain season, such as the Indian monsoon break, was seen over southwestern Japan.

\section{Precipitation over China}

The precipitation in $\mathrm{C}_{25}$ and $\mathrm{C}_{30}$ continued throughout for May $\sim$ July period while that in $\mathrm{C}_{35}$ was seen for 15 June $\sim 20$ July. Murakami and Huang (1984) defined the onset of Meiyu in $\mathrm{C}_{35}$ on 16 June. After the onset, no significant break of monsoon rains occurred.
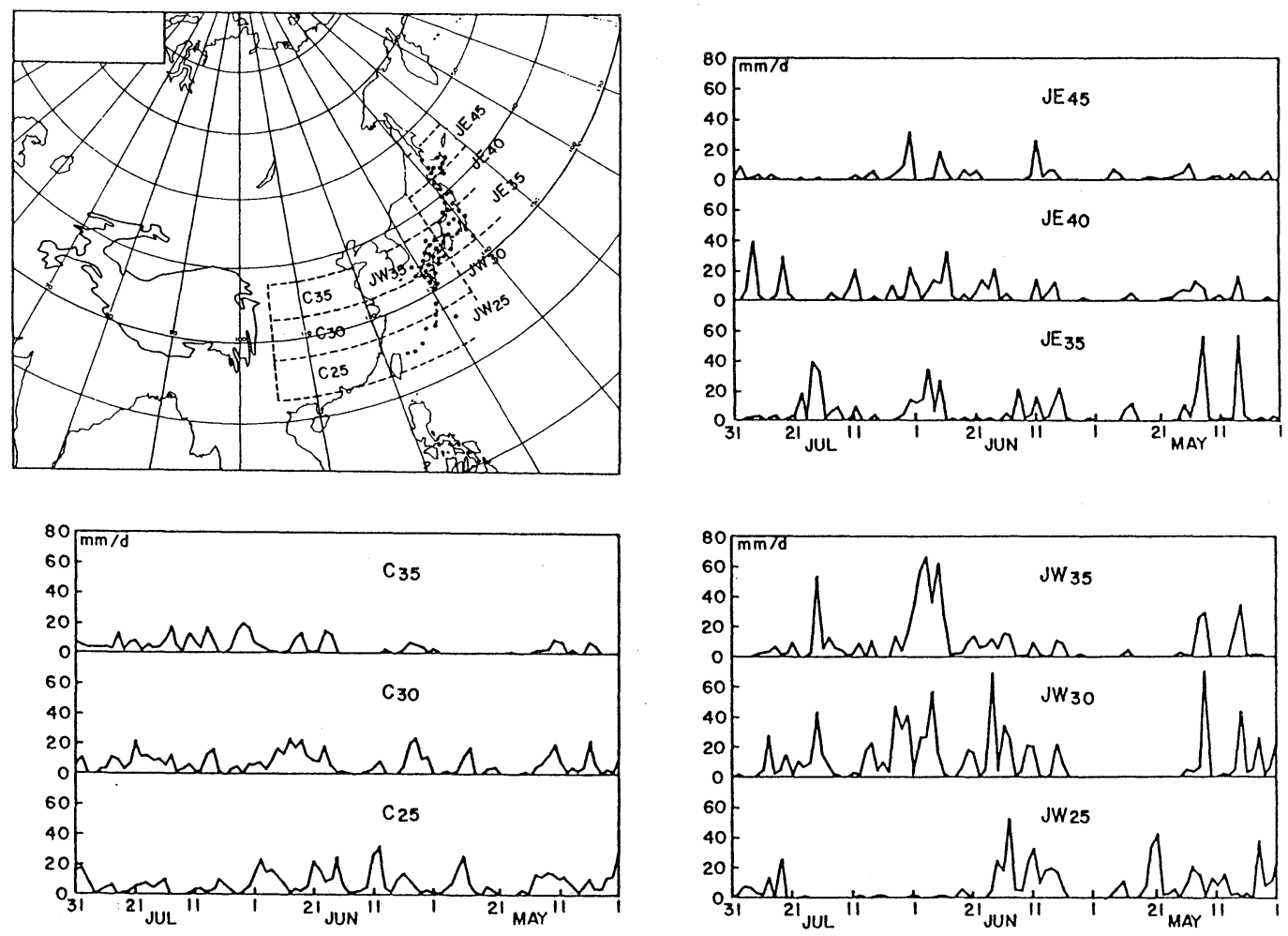

Fig. 1 The time-series of daily precipitation averaged over each of 9 areas indicated in the top -left map for May - July 1979. The blacked circles indicate the observation stations. The data on China were obtained from Murakami and Huang (1984). 


\section{Precipitation over India}

The monsoon onset on India occurred around 15 June. The peak of the monsoon precipitation was seen in $20 \sim 30$ June. July was a break period of monsoon over almost all part of India. The second eminent precipitation peak appeared around 1 August (Luo and Yanai, 1983; Murakami, M., 1985). The Meiyu and Baiyu precipitation were still intense in $5 \sim 20$ July, which was the break period of Indian monsoon.

\section{Subdivision of the analyzed period}

On the basis of the distribution and the amount of the precipitation over Japan and China, the analyzed period was subdivided into the four period as indicated in Table 1.

In the following sections, we describe the characteristics of the large-scale features in these subperiods by presenting the 10-day averaged fields of various meteorological elements.
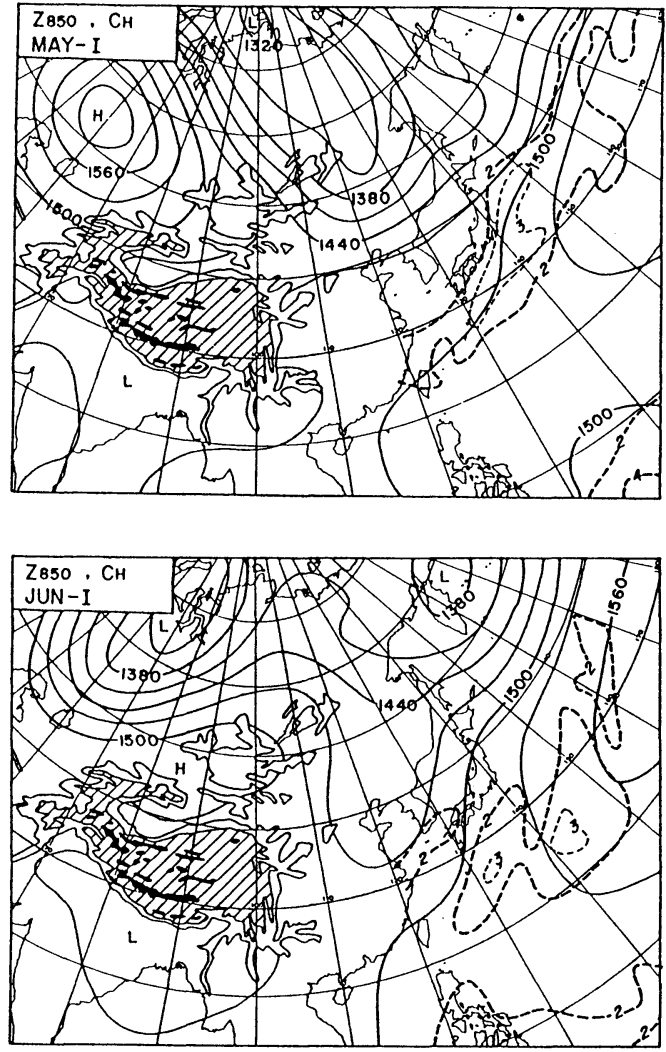

Table 1 Sub-periods of the Baiu season in 1979.

\begin{tabular}{|c|c|c|}
\hline Sub-Period & Baiu/Meiyu & Indian Monsoon \\
\hline May I $(1-10)$ & Pre-Baiu & \multirow{4}{*}{ Pre-Onset } \\
\hline May II $(11-20)$ & - & \\
\hline May III $(21-31)$ & Early Baiu & \\
\hline Jun I $(1-10)$ & - & \\
\hline Jun II $(11-20)$ & peak Baiu & Onset \\
\hline Jun III $(21-30)$ & - & \multirow{2}{*}{ Peak Monsoon } \\
\hline Jun I $(1-10)$ & - & \\
\hline Jul II $(11-20)$ & - & \multirow[t]{2}{*}{ Break Monsoon } \\
\hline Jul III $(21-31)$ & Post-Baiu & \\
\hline Aug I $(1-10)$ & - & Second Peak \\
\hline
\end{tabular}

\section{Characteristics of height field}

Fig. 2 shows 10-day averaged $850 \mathrm{mb}$ height $\left(Z_{850}\right)$ and the high-cloud amount $\left(C_{H}\right.$; estimated only over sea areas) for May I, Jun I, Jun III and Jul III. Fig. 3 presents 10-day averaged $500 \mathrm{mb}$ height $\left(Z_{500}\right)$ and the time-variance of $Z_{850}$ in
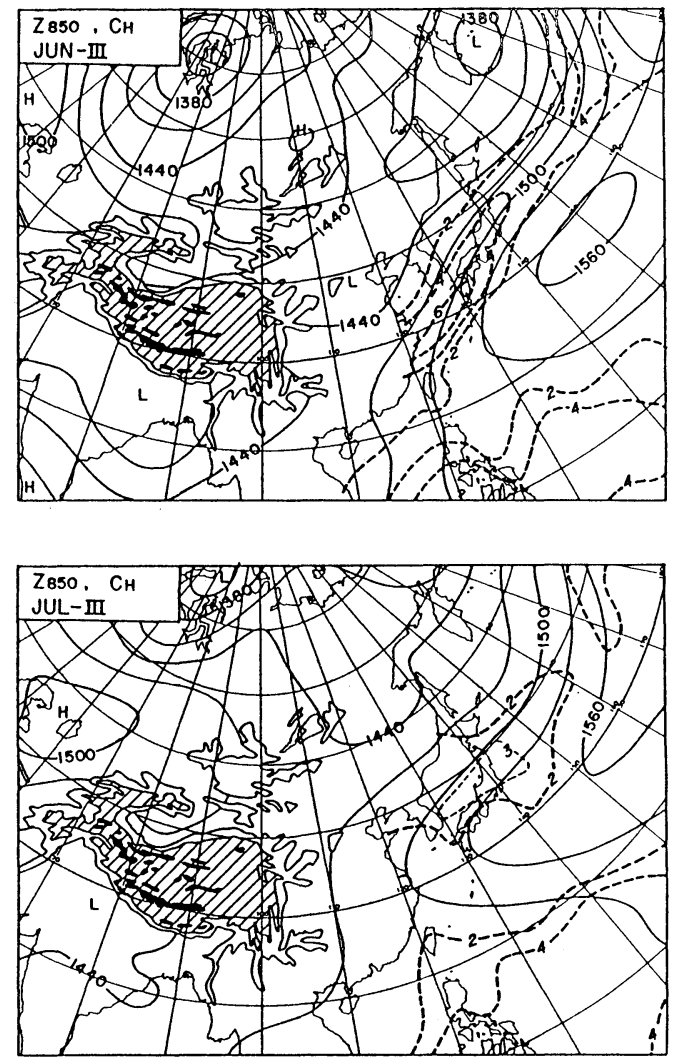

Fig. 2 The 10-day averaged $850 \mathrm{mb}$ height $\left(Z_{850}\right)$ and the high-cloud amount $\left(C_{H}\right.$ : estimated only over sea areas, dashed lines) for May I, Jun I, Jun III and Jul III, 1979. Contours of the topography of 1500,3000 and $5000 \mathrm{~m}$ are shown in the maps. 

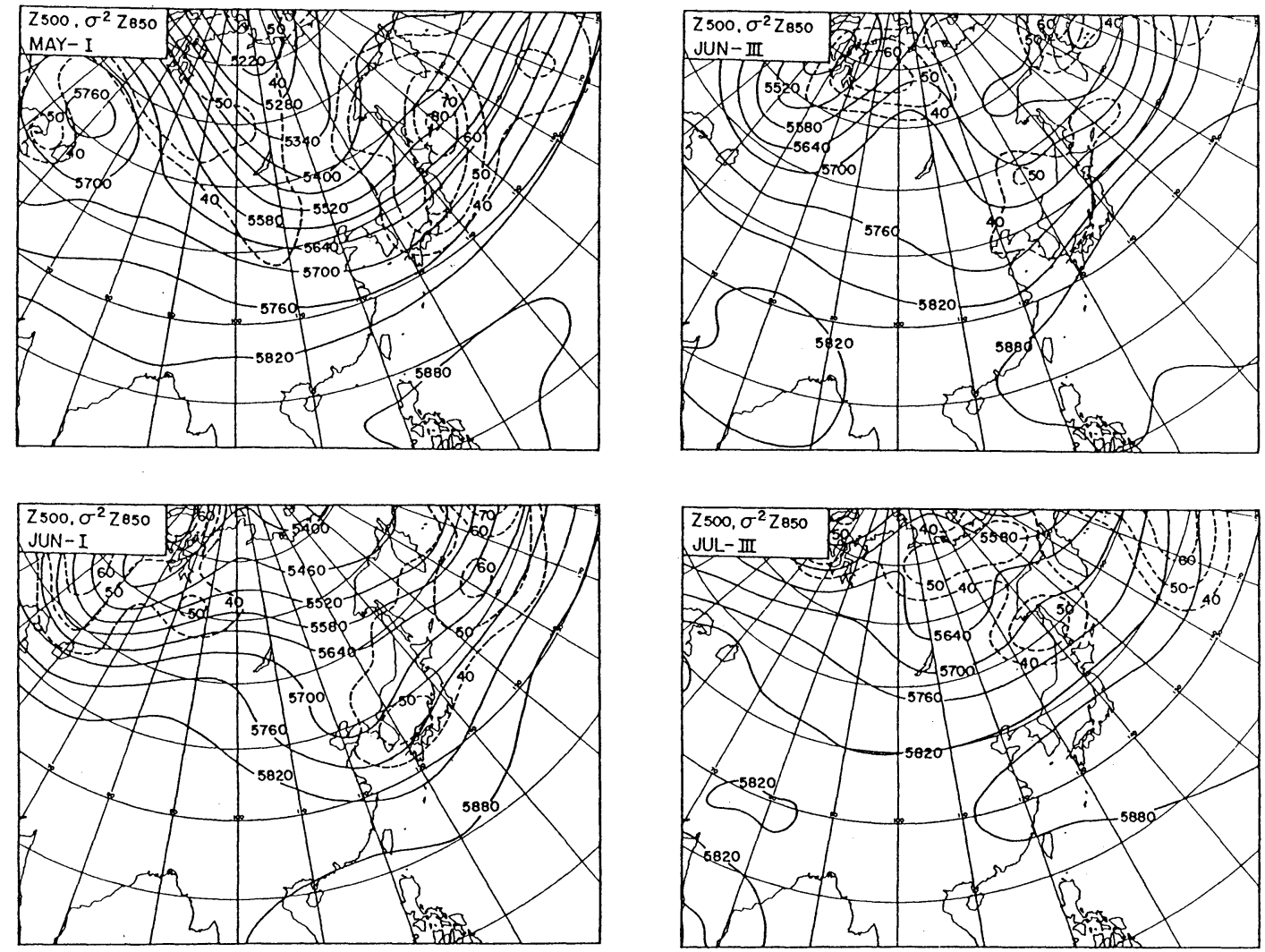

Fig. 3 The 10-day averaged $500 \mathrm{mb}$ height $\left(Z_{500}\right)$ and the time-variance of $Z_{850}$ in 10-day period $\left(\sigma^{2} Z_{850}\right.$, dashed lines) for May I, Jun I, Jun III and Jul III, 1979.

10-day period $\left(\sigma^{2} Z_{850}=1 / 20 \Sigma\left(Z_{850}-\bar{Z}_{850}\right)^{2}\right)$ for May I, Jun I, Jun III and Jul III.

\section{Pre-Baiu period}

A deep trough extended from a cyclone over the Taimyr Peninsula $\left(\sim 90^{\circ} \mathrm{N} / 100^{\circ} \mathrm{E}\right)$ to central Siberia and farther to the northeastern part of China $\left(\sim 45^{\circ} \mathrm{N} / 120^{\circ} \mathrm{E}\right)$. A developed anticyclone (ridge) was located over Kazakh, U.S.S.R. $\left(\sim 60^{\circ} \mathrm{N} /\right.$ $60^{\circ} \mathrm{E}$ ). There was the zone of strong height gradient (polar frontal zone) in $40 \sim 60^{\circ} \mathrm{N}$. The zone of large $\sigma^{2} Z_{850}$, which corresponded to the path of the major polar frontal cyclones was also seen in $40 \sim 50^{\circ} \mathrm{N}$. The zone of maximum $C_{H}$ was along the south side of the zone of large $\sigma^{2} Z_{850}$.

\section{Early-Baiu period}

The height field in the lower and middle troposphere changed rapidly in the transitional period between the pre- and early-Baiu. At $850 \mathrm{mb}$, there was a deep trough over the Ural
Mountains, extending from a cyclone over the Kara Sea $\left(\sim 70^{\circ} \mathrm{N} / 70^{\circ} \mathrm{E}\right)$ to the Caspian Sea $\left(\sim 45^{\circ} \mathrm{N} / 60^{\circ} \mathrm{E}\right)$.

A predominant ridge extended from the north of the Tibetan Plateau $\left(\sim 45^{\circ} \mathrm{N} / 90^{\circ} \mathrm{E}\right)$ to the Mongol and Sibirsk Plateau $\left(\sim 70^{\circ} \mathrm{N} /\right.$ $\left.120^{\circ} \mathrm{E}\right)$. This ridge is called "Baiu ridge" in the present paper. There was a trough extending from a stationary cyclone over the Bearing Sea $\left(\sim 60^{\circ} \mathrm{N} / 170^{\circ} \mathrm{E}\right.$; Bering cyclone) to the China Plain. $\left(\sim 35^{\circ} \mathrm{N} / 120^{\circ} \mathrm{E}\right)$. This trough is called "Baiu trough" in this paper.

The zone of large $\sigma^{2} Z_{850}$ was located along the southeastern side of the $500 \mathrm{mb}$ Baiu trough, and the maximum zone of $C_{H}$ (Baiu frontal cloud zone) was along the south side of the zone of maximum $\sigma^{2} Z_{850}$. The location of this cloud zone coincided approximately with the northwestern periphery of the Pacific anticyclone. The Baiu fronal zone was $\sim 1500 \mathrm{~km}$ south of the Baiu trough while the Meiyu frontal 
precipitation zone was close to the trough. The aforementioned spatial relations among the Baiu trough, the zone of maximum $\sigma^{2} Z_{850}$, the cloud zone and the Pacific anticyclone were seen throughout the early- and peak-period of Baiu.

The southern maximum zone of $C_{H}$ (ITCZ cloud zone) was seen along the southwestern periphery $\left(\sim 10^{\circ} \mathrm{N}\right)$ of the Pacific anticyclone.

\section{Peak period of Baiu}

In this period, the zone of maximum precipitation over Japan and China was along $\sim 30^{\circ} \mathrm{N}$, and the precipitation attained its maximum intensity. The monsoon precipitation over western India also reached to maximum intensity in Jun III $\sim \mathrm{Jul} \mathrm{I}$.

At $850 \mathrm{mb}$, the Pacific anticyclone shifted gradually northward and its E-W axis was over $\sim 27^{\circ} \mathrm{N}$ in Jun III. The Kara cyclone $\sim$ Ural trough and the Baiu ridge remained unchanged for June. The Baiu trough attained the full extension in this period. It extended WSW-ward from the Bering cyclone to the eastern foot of the Tibetan Plateau $\left(\sim 35^{\circ} \mathrm{N} / 105^{\circ} \mathrm{E}\right)$ via the Okhotsk Sea* and the northeastern part of China. Strong height gradient was seen between the Baiu trough and the Pacific anticyclone in the area east of $140^{\circ} \mathrm{E}$.

Jun III and Jul I were the peak period of the Indian monsoon. There was a large low-pressure area over India and the strong height gradient (i.e., zone of strong westerly wind) was over India in $\sim 20^{\circ} \mathrm{N}$. The cloud of ITCZ, which was along the southwestern periphery of the Pacific anticyclone, increased significantly in this period.

At $500 \mathrm{mb}$, the Baiu ridge indicated the

\footnotetext{
* The development of anticyclone over the Okhotsk Sea (Okhotsk anticyclone) has been thought to be one of the factors to maintain the Baiu front, because the NE wind along the SE hem of it advects cold air toward the Baiu front (Takahashi, 1969). However, the Okhotsk anticyclone was not seen on the 10-day averaged $850 \mathrm{mb}$ height field. Since, usually the Okhotsk anticyclone appeared in the lower troposphere, and moved out within a few or several days (Suginaka, 1965), it is not necessarily recognized on the 10-day averaged $850 \mathrm{mb}$ height map, except the case of unusual long persistence (Ninomiya and Mizuno, (1985).
}
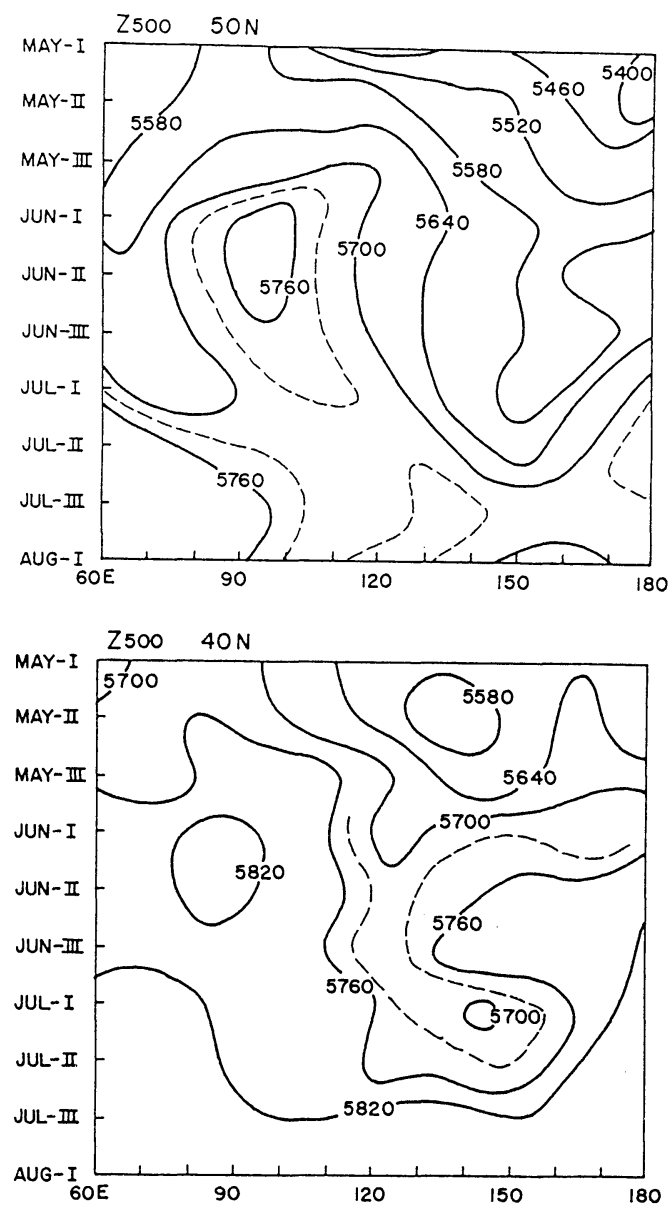

Fig. 4 The longitude-time section of 10-day averaged $500 \mathrm{mb}$ height $\left(Z_{500}\right)$ at 50 and $40^{\circ} \mathrm{N}$.

maximum extension toward the high latitudes. Although the height gradient in the polar region decreased significantly in this period, the large height gradient in $\sim 40^{\circ} \mathrm{N} / 130 \sim 170^{\circ} \mathrm{E}$ were sustained between the Baiu trough and the Pacific anticyclone.

\section{Post Baiu period}

The large-scale height field over East Asia changed rapidly in the transitional period between the Baiu period and the mid-summer. The height gradient in the lower and the middle troposphere weakened rapidly in Jul II and III. The Ural trough retired poleward. In association with the decay of the Bering cyclone and the Baiu trough, a zonal height pattern with very weak height gradient was established over the East Asia and the north Pacific. The E-W axis 
of the Pacific anticyclone was along $\sim 30^{\circ} \mathrm{N}$. The zone of maximum cloud and precipitation shifted over $\sim 40^{\circ} \mathrm{N}$, and the amount of cloud and rainfall decreased.

\section{Variation of the Baiu trough and ridge}

The longitude-time sections of 10-day averaged $500 \mathrm{mb}$ height, $850 \mathrm{mb}$ height and that of $\sigma^{2} Z_{850}$ are presented in Figs. 4, 5 and 6 respectively.

The $500 \mathrm{mb}$ Baiu ridge was most predominant at $50^{\circ} \mathrm{N}$ in Jun $\mathrm{I} \sim \mathrm{Jul}$ II. It moved eastward from $\sim 95^{\circ} \mathrm{E}$ (Jun I) to $\sim 120^{\circ} \mathrm{E}$ (Jul II). The $500 \mathrm{mb}$ Baiu trough was most evident at $40^{\circ} \mathrm{N}$. It moved westward from $\sim 135^{\circ} \mathrm{E}$ (May III) to $\sim 120^{\circ} \mathrm{E}$ (Jun II) and then eastward to $\sim 145^{\circ} \mathrm{E}$ (Jul II). The $850 \mathrm{mb}$ Baiu trough was most evident at $50^{\circ} \mathrm{N}$. Its maximum westward extension occurred in the peak period of precipitation (Jun III $\sim$ Jul I). The Baiu trough disappeared around Jul III.

The hatched areas in Fig. 6 shows the area of large $\sigma^{2} Z_{850}$ exceeding $40 \mathrm{~m}^{2}$. It moved westward from $\sim 160^{\circ} \mathrm{E}$ (May II) to $\sim 130^{\circ} \mathrm{E}$ (Jun III) and then rapidly eastward to $\sim 180^{\circ} \mathrm{E}$ (Jul III). The northeastward shift of the area of maximum cyclone activity around $40^{\circ} \mathrm{N}$ was deeply related with the seasonal variation of the Baiu trough.

Another conspicuous feature seen in the longitude-time section of $Z_{850}$ at $40^{\circ} \mathrm{N}$ (Fig. 5, bottom) was the quasi-periodic variation in the height field with $\sim 40$-day period. This intraseasonal variation will be examined in Section 7.

\section{Characteristics of wind field.}

The 10-day averaged wind field at 850,700 and $300 \mathrm{mb}$ for May I, Jun I, Jun III and Jul III are presented in Figs. 7, 8 and 9.

\section{Pre-Baiu period}

The anticyclonic circulation over Kazakh, U.S.S.R. $\left(\sim 60^{\circ} \mathrm{N} / 60^{\circ} \mathrm{E}\right)$ and the cyclonic circulation over Siberia were the major circulation systems in the middle $\sim$ high latitudes. The confluence of the polar and subtropical jet streams to the east of the Siberia trough formed the strong wind zone over the Pacific.

The "transverse trough", i.e., the shear line between the easterly wind in the north side and
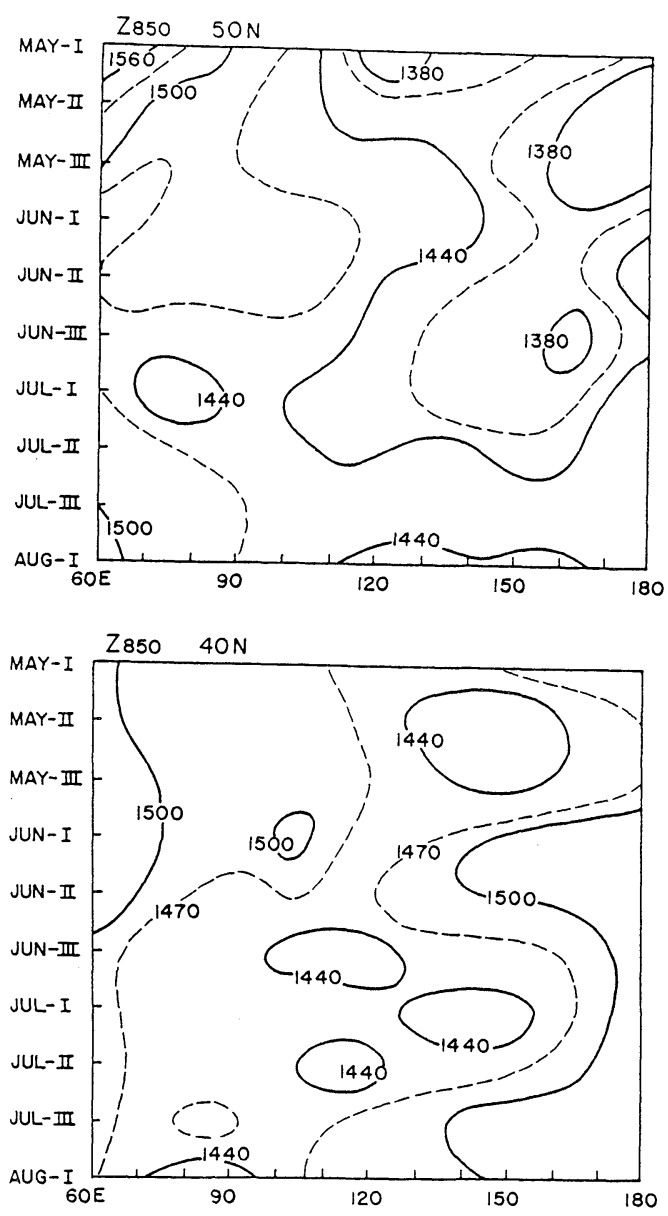

Fig. 5 The longitude-time section of 10-day averaged $850 \mathrm{mb}$ height $\left(Z_{850}\right)$ at 50 and $40^{\circ} \mathrm{N}$.

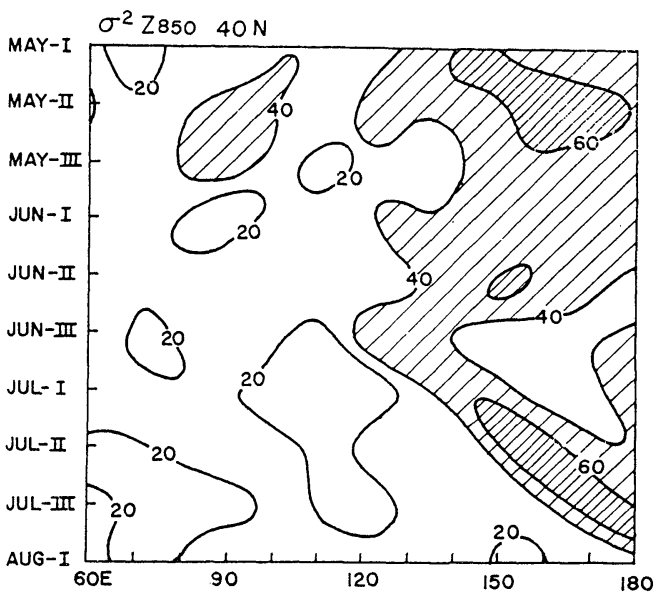

Fig. 6 The longitude-time section of time-variance of $Z_{850}$ in 10 -day period $\left(\sigma^{2} Z_{850}\right)$ at $40^{\circ} \mathrm{N}$. 

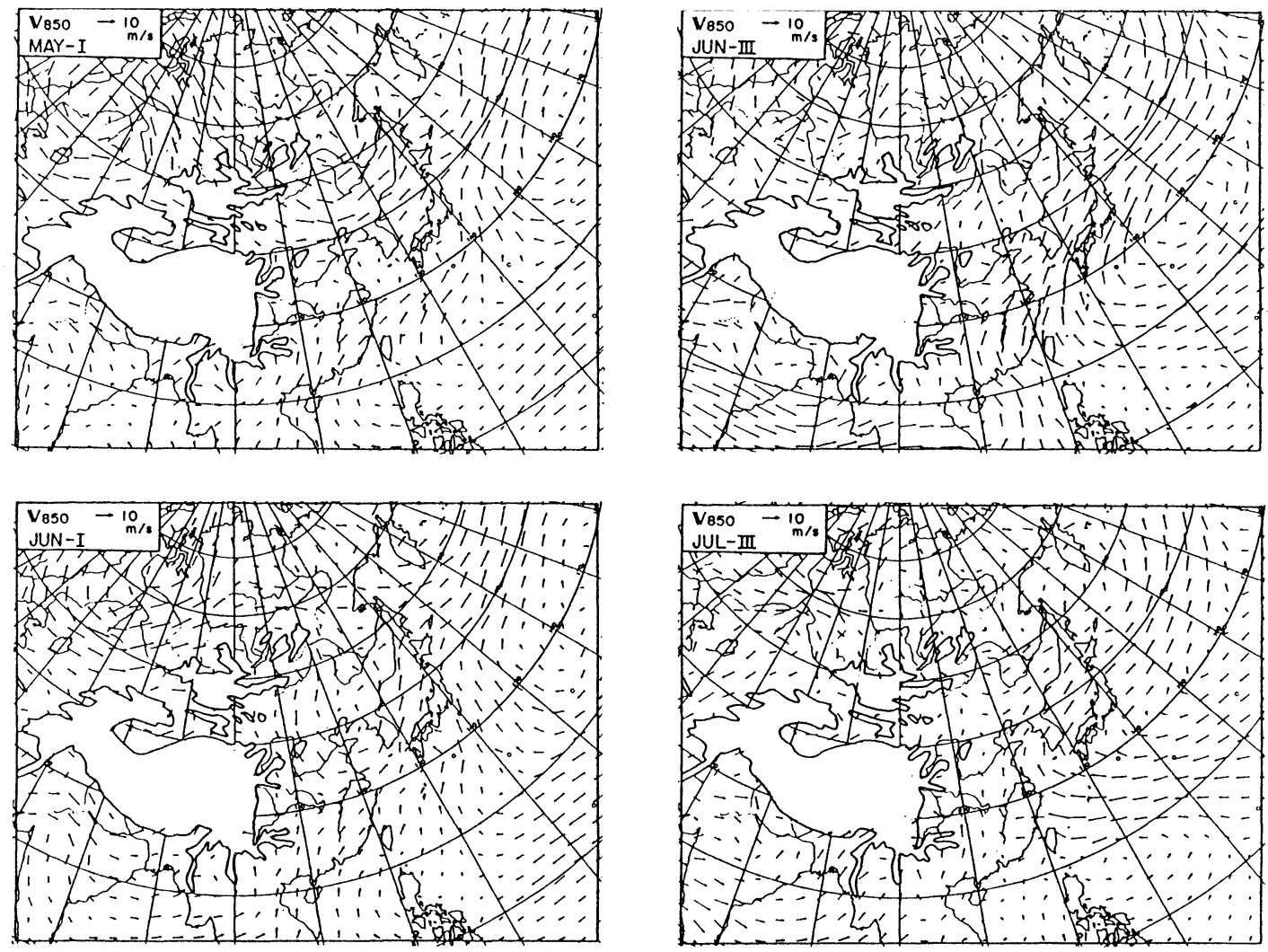

Fig. 7 The 10-day averaged $850 \mathrm{mb}$ wind velocity $\left(\boldsymbol{V}_{850}\right)$ for May I, Jun I, Jun III and Jul III, 1979.

the westerly wind in the south side, extending eastward from the eastern foot of the Tibetan Plateau (Luo and Yanai, 1983) was seen in the pre-Baiu season. The zone of strong $700 \mathrm{mb}$ wind along the south side of the Tibetan Plateau extending eastward to the strong wind zone over the Pacific was also one of the characteristics in the pre-Baiu period.

\section{Early Baiu period}

The wind field over East Asia changed rapidly from the pre- to early-Baiu period. In the middle $\sim$ high latitudes, the circulations of the Ural trough, the Baiu ridge and the Bering cyclone Baiu trough were formed in the early Baiu period. The northerly wind in $850 \sim 700 \mathrm{mb}$ between the Baiu ridge and the Baiu trough $\left(55 \sim 30^{\circ} \mathrm{N} / 105 \sim 125^{\circ} \mathrm{E}\right)$ was an important feature. This is called as Baiu-trough-northerly wind in this paper. A convergence/confluence line was formed between the Baiu-trough-northerly wind and the southerly wind from the South
China Sea. This is named as Baiu shear line in this paper. At $700 \mathrm{mb}$, the westerly wind in $25 \sim 30^{\circ} \mathrm{N}$ zone weakened over Indo-China Peninsula, and the strong wind zone over India $\left(\sim 25^{\circ} \mathrm{N} / 65 \sim 95^{\circ} \mathrm{E}\right)$ were separated from that over the Pacific $\left(30 \sim 35^{\circ} \mathrm{N} / 120 \sim 180^{\circ} \mathrm{E}\right)$.

At $300 \mathrm{mb}$, a trough was formed over the western part of the Tibetan Plateau and staied there during the Baiu season. The strong anticyclonic circulation systems developed over India $\sim$ Bay of Bengal and Indo-China $\sim$ South China Sea areas.

\section{Peak period of Baiu}

With the full development of the Baiu trough, the Baiu trough north $\sim$ northeasterly wind in $850 \sim 700 \mathrm{mb}$ was intensified in the peak period of Baiu. As this strong north $\sim$ northeastrly wind appeared along the eastern edge of high-land area (see $1500 \mathrm{~m}$ contour line in Fig. 7), some orographic effect was infered.

The monsoon precipitation attained its 

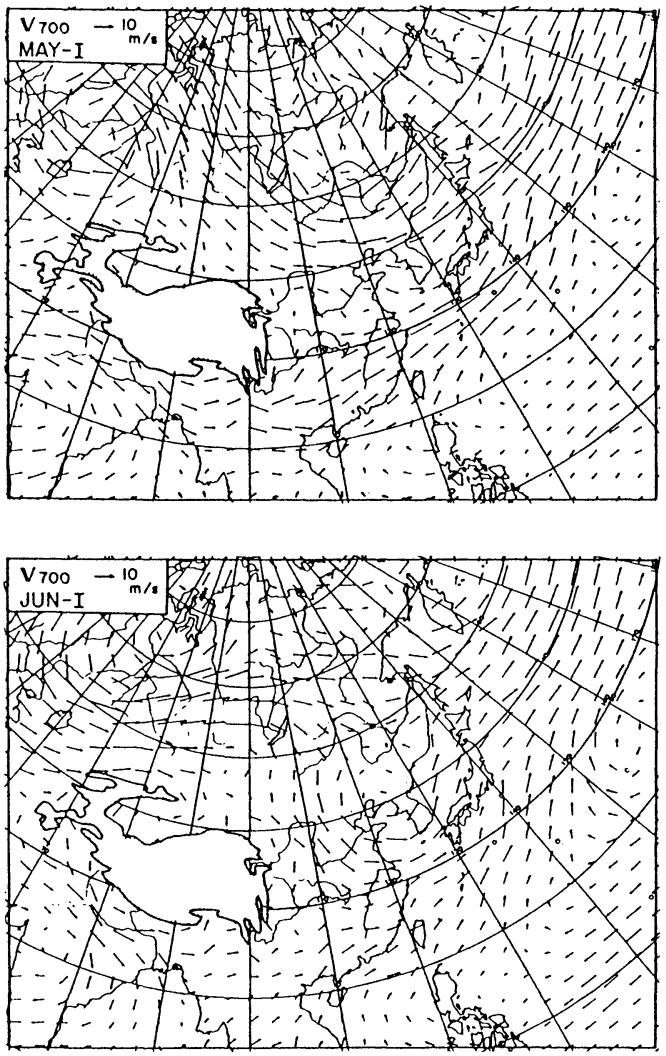
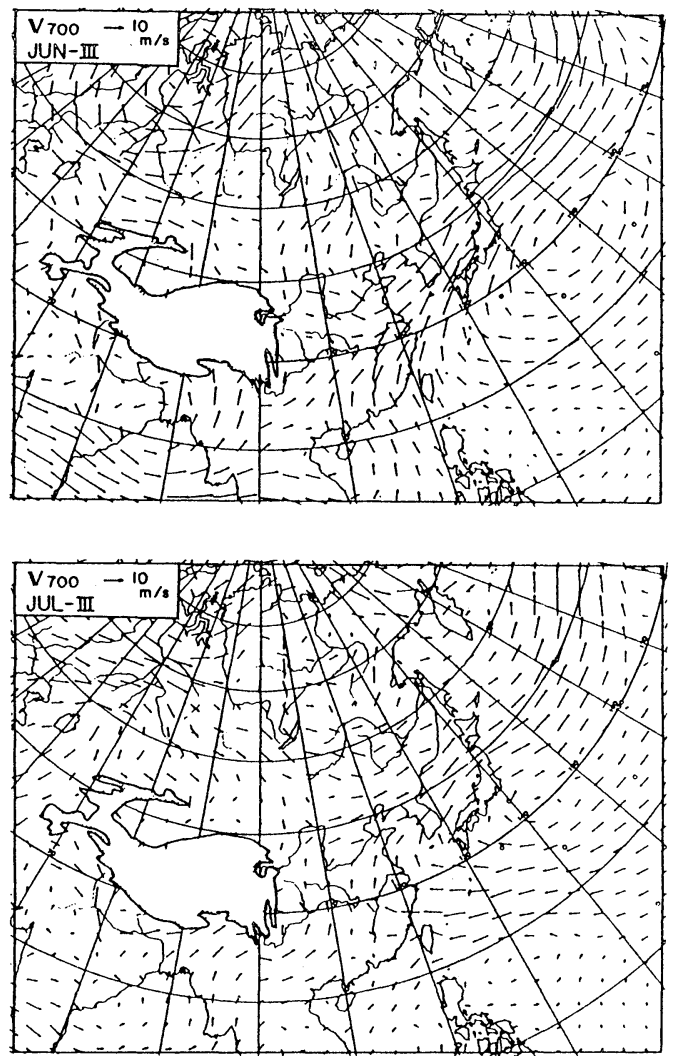

Fig. 8 The 10-day averaged $700 \mathrm{mb}$ wind velocity $\left(\boldsymbol{V}_{700}\right)$ for May I, Jun I, Jun III and Jul III, 1979.

maximum intensity over western India in Jun III $\sim$ Jul I. In $850 \sim 700 \mathrm{mb}$, the cyclonic circulation over the Bay of Bengal $\left(\sim 23^{\circ} \mathrm{N} /\right.$ $\left.80 \sim 95^{\circ} \mathrm{E}\right)$ and the westerly flow were intensified over India $\sim$ south Bengal Bay $\left(\sim 20^{\circ} \mathrm{N} /\right.$ $70 \sim 95^{\circ} \mathrm{E}$ ). A trough (shear line) extended southeastward from the southeastern foot of the Tibetan Plateau to the South China Sea and farther to ITCZ along the southwestern periphery of the Pacific anticyclone. The southerly wind from the South China Sea to south central China was rapidly intensified in this period. Concurrently, the Baiu shear line was significantly intensified.

The Baiu frontal zone was associated with low-level convergence caused by the confluence of the SW wind along the northwestern periphery of the Pacific anticyclone with the low-leveljet like WSW wind.

At $300 \mathrm{mb}$, the circulations of the Ural trough, the Baiu ridge and the Bering cyclone
Baiu trough were still predominant in the middle $\sim$ high latitudes. The double-jet streams, in the north and south side of the anticyclonic circulation over the Baiu ridge were seen in $85 \sim 120^{\circ} \mathrm{E}$. Three developed anticyclonic circulations, over India $\sim$ Pakistan area, Indo-China area and the Pacific, aligned to the south of the subtropical jet stream.

\section{Post Baiu period}

As the Baiu trough vanished, the Baiu-trough north $\sim$ northeasterly wind weakened rapidly. With the northward shift of the Pacific anticyclone, the southerly wind over China and southwesterly wind over Japan weakened too. At $300 \mathrm{mb}$, the anticyclonic circulations were predominant over $30^{\circ} \mathrm{N}$.

\section{Characteristics of thermal field}

Fig. 10 shows the 10-day averaged $850 \mathrm{mb}$ temperature $\left(T_{850}\right)$ for May I, Jun I, Jun III and 

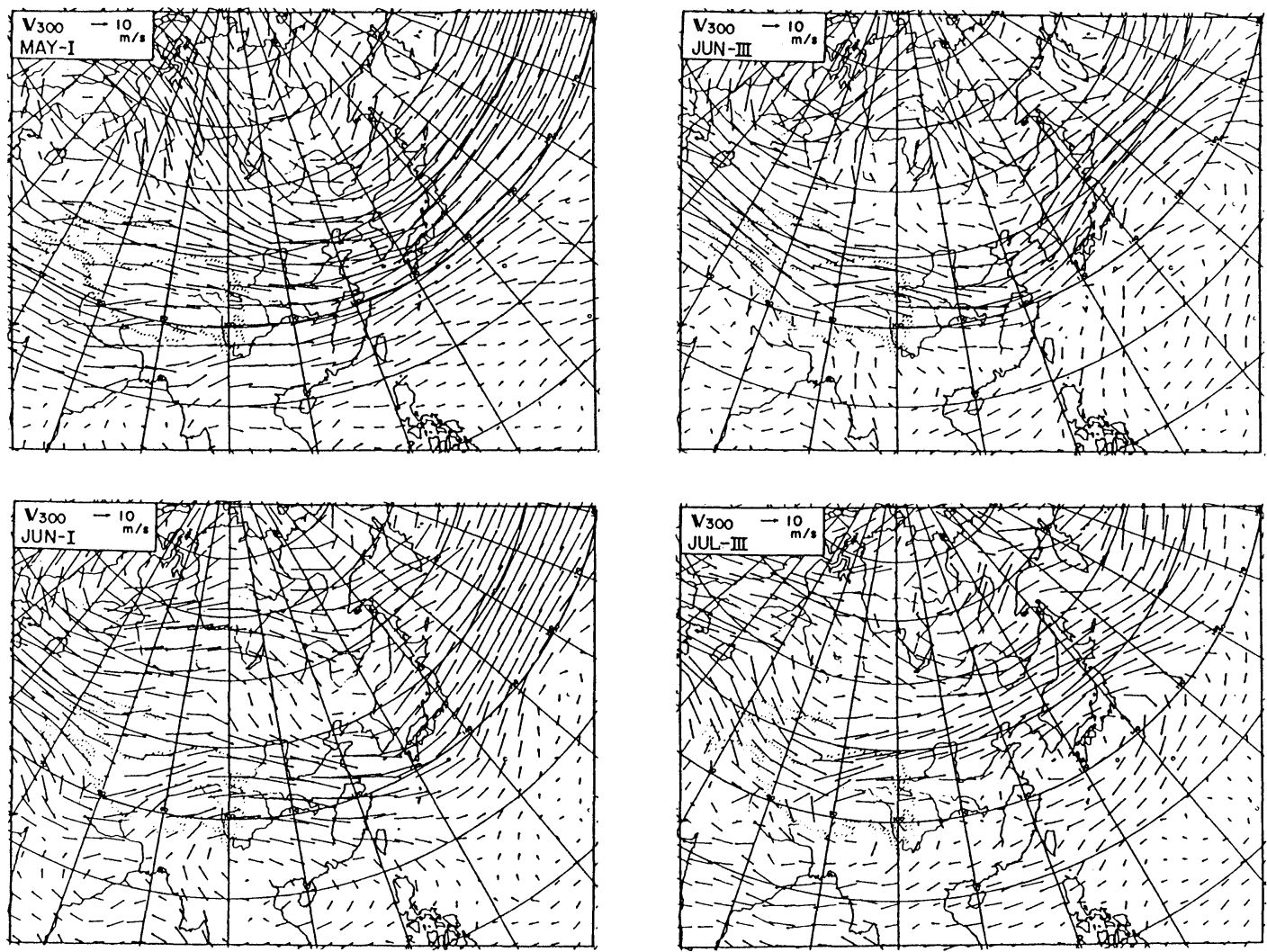

Fig. 9 The 10-day averaged $300 \mathrm{mb}$ wind velocity $\left(\boldsymbol{V}_{\mathbf{3 0 0}}\right)$ for May I, Jun I, Jun III and Jul III, 1979.

Jul III. Fig. 11 presents the 10-day averaged $850 \mathrm{mb}$ equivalent potential temperature $\left(\theta e_{850}\right)$ and the difference of $\theta e$ between 700 and 850 $\mathrm{mb}\left(\theta e_{700}-\theta e_{850}\right)$ for the same periods to these in Fig. 10. The longitude-time sections of 10-day averaged $850 \mathrm{mb}$ temperature for May $\mathrm{I} \sim$ Aug $\mathrm{I}$ at 50 and $40^{\circ} \mathrm{N}$ are presented in Fig. 12.

\section{Pre-Baiu period}

In the pre-Baiu period, the horizontal temperature gradient $(\nabla T)$ was strong ir the area to the north of $\sim 30^{\circ} \mathrm{N}$. In $30 \sim 60^{\circ} \mathrm{N}$ zone, the isotherms ran approximately parallel with the latitude circles, and the continent-ocean temperature contrast was small (Fig. 12).

The moist tropical airmass $\left(\theta e_{850}>340 \mathrm{~K}\right)$ covered the Bay of Bengal, Indo-China and the South China Sea. The areas to the north of $30^{\circ} \mathrm{N}$ were convectively stable $\left(\theta e_{700}-\theta e_{850}>\right.$ $0 \mathrm{~K})$. The southern part of China $\left(>30^{\circ} \mathrm{N}\right)$ was the most stable area $\left(\theta e_{700}-\theta e_{850}>5 \mathrm{~K}\right)$.

\section{Early Baiu period}

The $850 \mathrm{mb}$ temperature in $40 \sim 70^{\circ} \mathrm{N}$ over the Continent rose rapidly in May $\sim$ June. The temperature rise was most pronounced $\left(\sim 12^{\circ} \mathrm{C} /\right.$ month) over the high-land areas (Mongol and Sibirsk Plateau). Kato (1985) pointed out that this temperature rise was mainly due to the warming of air heated by insolation. At the same time, $\nabla T$ over the Continental part of China $\left(20 \sim 40^{\circ} \mathrm{N} / 100 \sim 120^{\circ} \mathrm{E}\right)$ decreased rapidly. The Meiyu front over China lost the characteristic feature of typical polar front with strong $\nabla T$ during the early Baiu period.

Convective stability in the lower troposphere also changed rapidly in May $\sim$ June. The isoline of $\left(\theta e_{700}-\theta e_{850}\right)$ labeled by $0 \mathrm{~K}$ shifted northward from $\sim 25^{\circ} \mathrm{N}$ (May I) to $\sim 50^{\circ} \mathrm{N}$ (Jun I) over China. The aforementioned change, i.e., the decrease of $\nabla T$ and the increase of convective instability in the Meiyu precipitation zone, was one of the conspicuous features found from the 

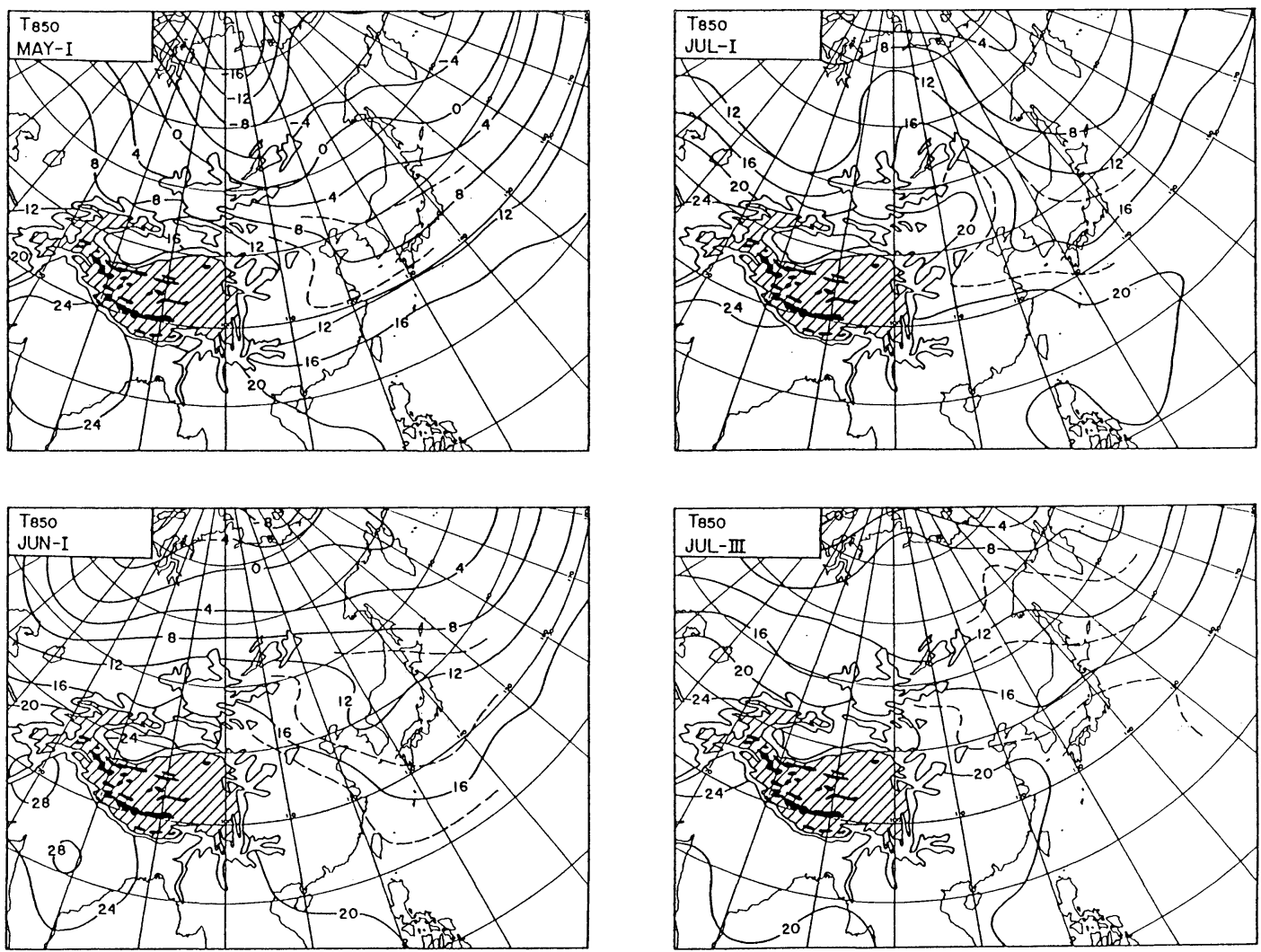

Fig. 10 The 10-day averaged $850 \mathrm{mb}$ temperature $\left(T_{850}\right)$ for May I, Jun I, Jul I and Jul III, 1979.

pre- to early-Baiu period.

On the other hand, the temperature rise was less pronounced ( $4 \mathrm{C} /$ month) over the Pacific to the north of $\sim 35^{\circ} \mathrm{N}$. The vast cold ocean prevented the warming of air. The cold advection in the west side of the Bering cyclone worked to sustain the low temperature over the northwestern Pacific. As the result, the strong $\nabla T$ in $30 \sim 40^{\circ} \mathrm{N}$ zone over the Pacific, and the large Continent-Pacific temperature contrast in $40 \sim 70^{\circ} \mathrm{N}$ were maintained throughout the Baiu period (Fig. 12).

\section{Peak Baiu period}

The rise of $850 \mathrm{mb}$ temperature was still large over the high-land area in June $\sim$ July $\left(\sim 8^{\circ} \mathrm{C} /\right.$ month). The area of high temperature protruded northward from the Tibetan Plateau to the Sibirsk Plateau $\left(\sim 70^{\circ} \mathrm{N} / 100^{\circ} \mathrm{E}\right)$. This temperature rise was partly due to the warm-air advection by the southerly wind in the west side of the Baiu ridge.
In accordance with the full development of the Baiu trough, the tongue-shaped area of low temperature extended from the Bering Sea to the Japan Sea, the Yellow Sea, and farther to the central part of China $\left(\sim 35^{\circ} \mathrm{N} / 105^{\circ} \mathrm{E}\right)$. The formation of cold zone was due to the coldair advection by the Baiu-trough $\mathrm{N} \sim \mathrm{NE}$ wind. The large cloudiness in the Meiyu and Baiu frontal zone also prevents the warming due to isolation.

The $340 \mathrm{~K}$ isoline of $\theta e_{850}$, which indicated the northern boundary of the tropical marine airmass, was located along $\sim 35^{\circ} \mathrm{N}$. The narrow area of nearly moist-neutral stratification $\left(\theta e_{700}\right.$ $-\theta e_{850} \approx 0$ ) was extending along $\sim 35^{\circ} \mathrm{N}$ from $100^{\circ} \mathrm{E}$ to $135^{\circ} \mathrm{E}$. The successive development of convective clouds in the Baiu/Meiyu frontal zone worked to form the zone of moist-neutral layer. Similar feature was analysed for the other years by Matsumoto et al. (1971) and Akiyama (1973). 

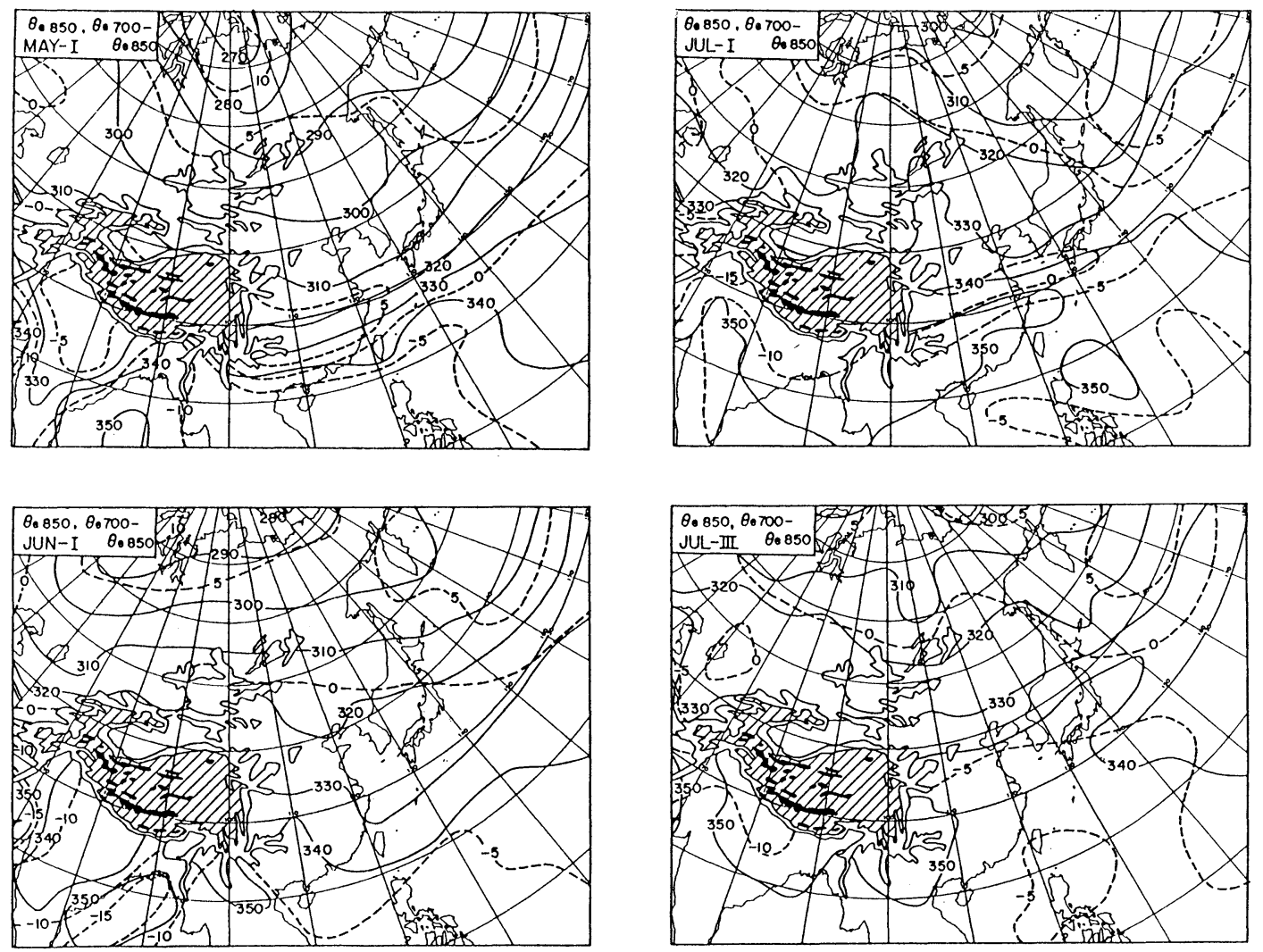

Fig. 11 The 10-day averaged $850 \mathrm{mb}$ equivalent potential temperature $\left(\theta e_{850}\right)$ and $\left(\theta e_{700}-\theta e_{850}\right.$, dashed lines) for May I, Jun I, Jul I and Jul III, 1979.

\section{Post Baiu period}

The temperature field changed rapidly in the transitional period between the Baiu period and the middle summer. Concurrent with the decay of the Baiu ridge, Baiu trough and the Bering cyclone, and with the northward shift of the Pacific anticyclone, the long-wave pattern of thermal field changed into the zonal pattern with weak $\nabla T$ in Jul III. The large temperature difference between the Continent and the Pacific disappeared too (Fig. 12).

\section{Difference between Meiyu and Baiu front}

The latitude-time section of 10-day averaged $850 \mathrm{mb}$ temperature along 110,130 and $150^{\circ} \mathrm{E}$ meridians are presented in Fig. 13. The data at grid point with $5^{\circ} \mathrm{Lat}$. interval were used.

The temperature variation was large over the Continent $\left(110^{\circ} \mathrm{E}\right)$. The period of high temperature in $30 \sim 60^{\circ} \mathrm{N}$ roughly coincided with the peak period of the Baiu ridge. The largest temperature rise occurred around May III (transition from the pre- to the early-Baiu period) and the secondary. rise around Jun III (transition from the early- to peak-Baiu period). Along $110^{\circ} \mathrm{E}$, the maximum zone of $\nabla T(\sim 10 \mathrm{~K} / 1000$ $\mathrm{km}$, in N-S direction) was in $50 \sim 70^{\circ} \mathrm{N}$ zone. The Meiyu frontal zone $\left(\sim 35^{\circ} \mathrm{N}\right)$ was located in the area of very weak $\nabla T$.

Along $130^{\circ} \mathrm{E}$, the temperature rise was gradual in $20 \sim 40^{\circ} \mathrm{N}$ zone. The maximum $\nabla T$ around $70^{\circ} \mathrm{N}$ was $\sim 10^{\circ} \mathrm{C} / 1000 \mathrm{~km}$, while $\nabla T$ in $30 \sim 60^{\circ} \mathrm{N}$, including the Baiu frontal zone, was $\sim 5^{\circ} \mathrm{C} / 1000 \mathrm{~km}$.

Over the Pacific $\left(150^{\circ} \mathrm{E}\right)$, temperature change was small during the Baiu season (May III $\sim$ Jul II). The temperature rise in $45 \sim 60^{\circ} \mathrm{N}$ zone in Jul II $\sim$ III was associated with the northward displacement of the Pacific anticyclone and with the weakening of the Bering cyclone. Strong $\nabla T$ of $\sim 10^{\circ} \mathrm{C} / 1000 \mathrm{~km}$ was maintained around 

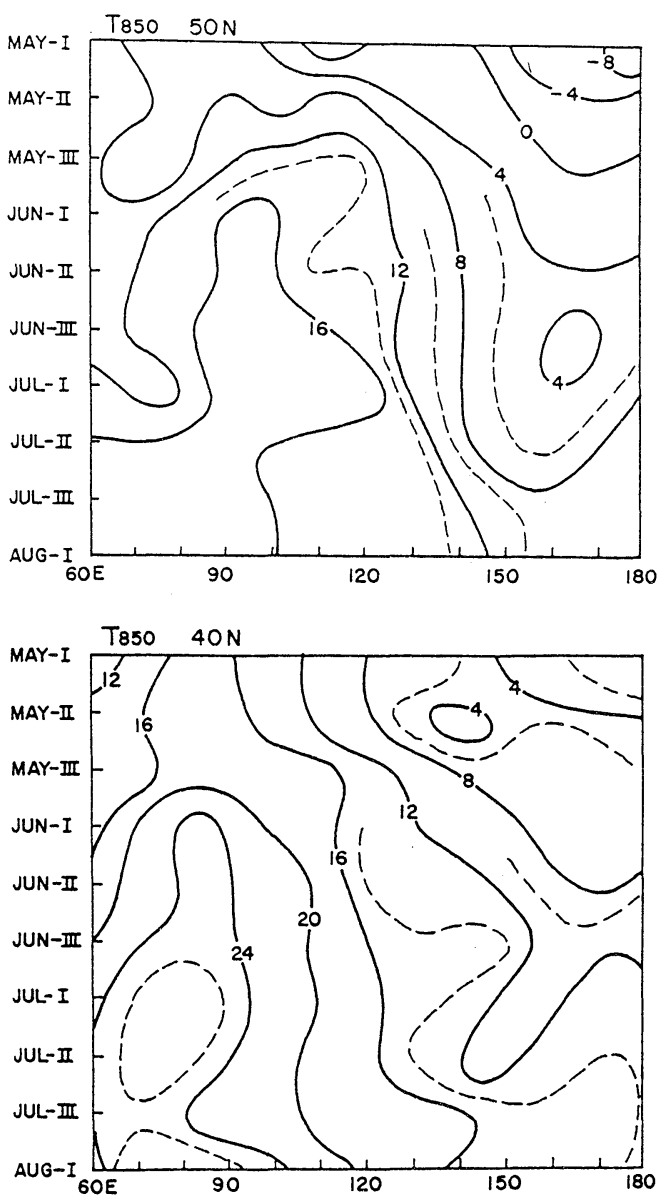

Fig. 12 The longitude-time section of 10-day averaged $850 \mathrm{mb}$ temperature $\left(T_{850}\right)$ at 50 and $40^{\circ} \mathrm{N}$.

$40^{\circ} \mathrm{N}$ during the peak period of Baiu (Jun II Jul II).

The aforementioned regional difference of the baroclinicity (thermal gradient) of the Meiyu/ Baiu front had strong influence on the evolution of the frontal disturbances. Because of the weak baroclinicity in the Meiyu front and the western part of Baiu front, the development of the frontal depressions was very slow and consequently the front remained quasi-stationary. Some of the weak frontal depression began to develop when they moved over the Pacific where the thermal gradient in the Baiu front was relatively large.
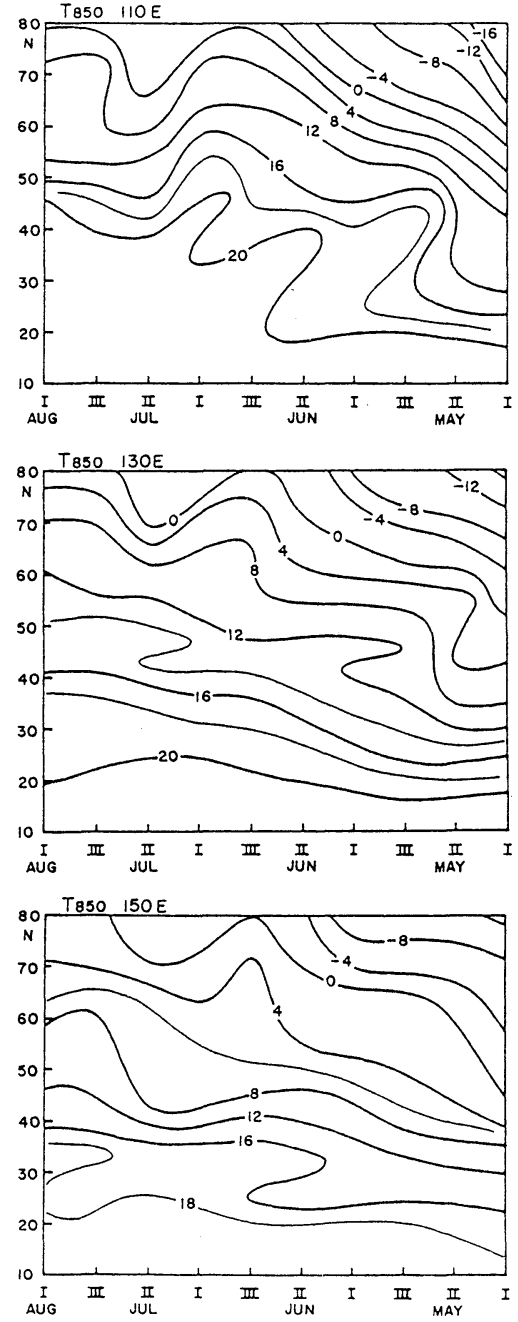

Fig. 13 The latitude-time section of 10-day averaged $850 \mathrm{mb}$ temperature at 110,130 and $150^{\circ} \mathrm{E}$.

\section{Moisture field and moisture flux}

\section{Moisture field}

Fig. 14 shows the 10-day averaged $850 \mathrm{mb}$ specific humidity $\left(q_{850}\right)$ for May I, Jun I, Jul I and Jul III. Fig. 15 presents the latitude-time section of $q_{850}$ along 110,130 and $150^{\circ} \mathrm{E}$ meridians. Data at grid points with $5^{\circ}$ Lat. interval were used for Fig. 15.

The time variation of $q_{850}$ was very large around India. It increase rapidly from $\sim 5 \mathrm{~g} / \mathrm{kg}$ (May I) to $\sim 15 \mathrm{~g} / \mathrm{kg}$ around the onset of monsoon (Jul I). On the one hand, the moisture 

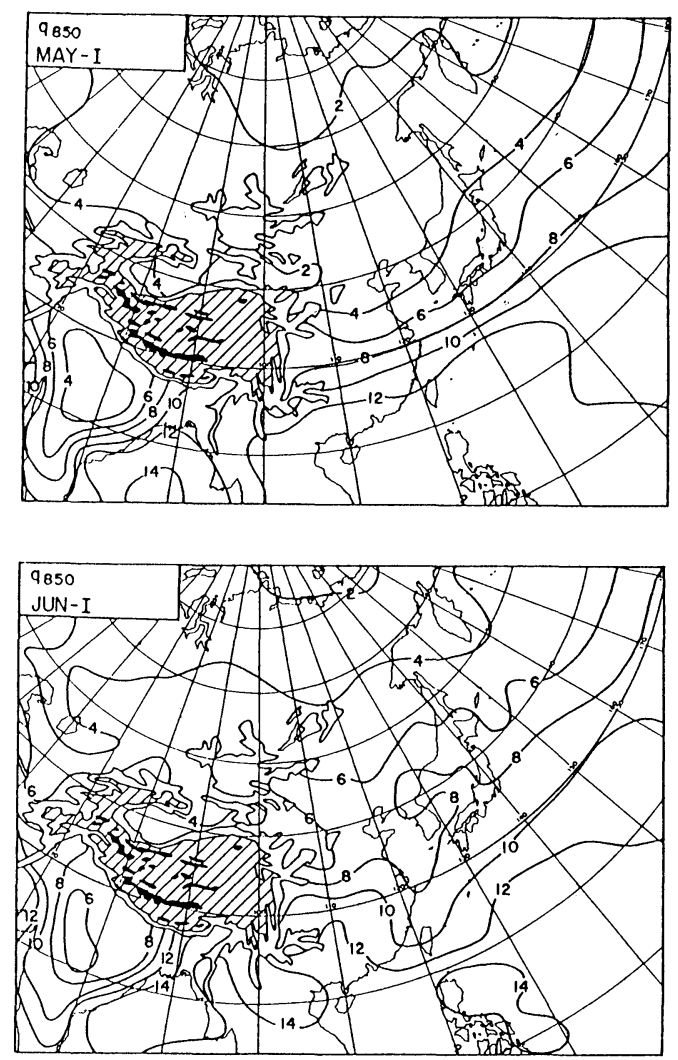
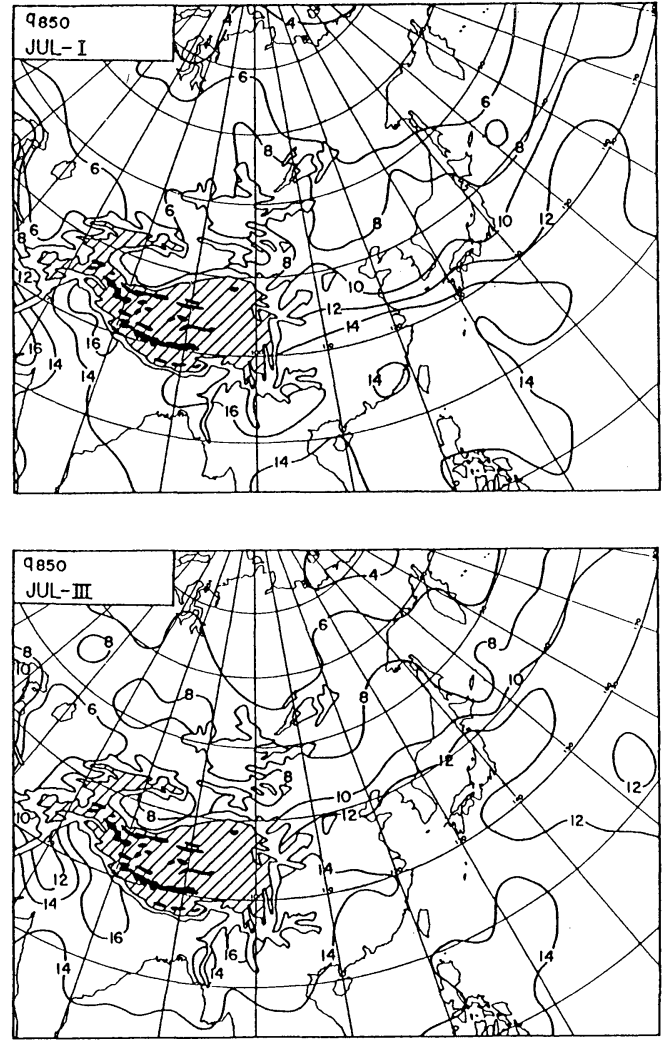

Fig. 14 The 10-day averaged $850 \mathrm{mb}$ specific humidity $\left(q_{850}\right)$ for May I, Jun I, Jul I and Jul III, 1979.

variation was small over the subtropical tropical Pacific, the Indo-China Peninsula and the Bay of Bengal. The $q_{850}$ over these areas was $12 \sim 14 \mathrm{~g} / \mathrm{kg}$ throughout the Baiu season. The $q_{850}$ in $40 \sim 70^{\circ} \mathrm{N}$ zone increased with the rate of $\sim 2 \mathrm{~g} / \mathrm{kg} /$ month in May $\sim$ July. The zonal pattern of the moisture field was seen in this zone.

The Meiyu and Baiu frontal zone are identified in the moisture field as the zone of maximum $\nabla q_{850}(5 \mathrm{~g} / \mathrm{kg} / 1000 \mathrm{~km})$. The largest $\nabla q_{850}$ of $5 \mathrm{~g} / \mathrm{kg} / 500 \mathrm{~km}$ was seen in the peak-Baiu period (Jun III $\sim$ Jul I). Over the Continent $\left(\sim 110^{\circ} \mathrm{E}\right)$, the rise of $q_{850}$ in $30 \sim 40^{\circ} \mathrm{N}$ occured around May III (transition to the early Baiu period) and around Jun III (peak period of Baiu and the onset period of monsoon). However, the largest moisture gradient $(\sim 8 \mathrm{~g} / \mathrm{kg} / 1000 \mathrm{~km})$ was maintained in $30 \sim 35 \mathrm{~N}$ zone. This indicates the effect of the Tibetan Plateau to block the northward intruion of moist air. The Baiu- trough-northeasterly flow also tends to block the northward intrusion of moist air. The moisture gradient in the Baiu frontal zone around $130^{\circ} \mathrm{E}$ was much smaller than these around $110^{\circ} \mathrm{E}$.

Over the Pacific $\left(150^{\circ} \mathrm{E}\right)$, the moisture increase in the Baiu period was very small. The strong $\nabla q_{850}(\sim 4 \mathrm{~g} / \mathrm{kg} / 1000 \mathrm{~km})$ was maintained in $30 \sim 40^{\circ} \mathrm{N}$ zone. This zone of maximum $\nabla q_{850}$ coincided approximately with that of maximum $\nabla T_{850}$. The low-q advection in the west side of the Bering cyclone sustained the moisture gradient over the Pacific.

\section{Moisture flux}

Fig. 16 shows the maps of 10-day averaged $850 \mathrm{mb}$ moisture flux $\left(\boldsymbol{V} \boldsymbol{q}_{850}\right)$ for May I, Jun I, Jun III and Jul III. The common feature of the moisture-flux fields seen in May $\sim$ July was the zone of maximum flux along the west $\sim$ northwestern periphery of the Pacific anticyclone. 

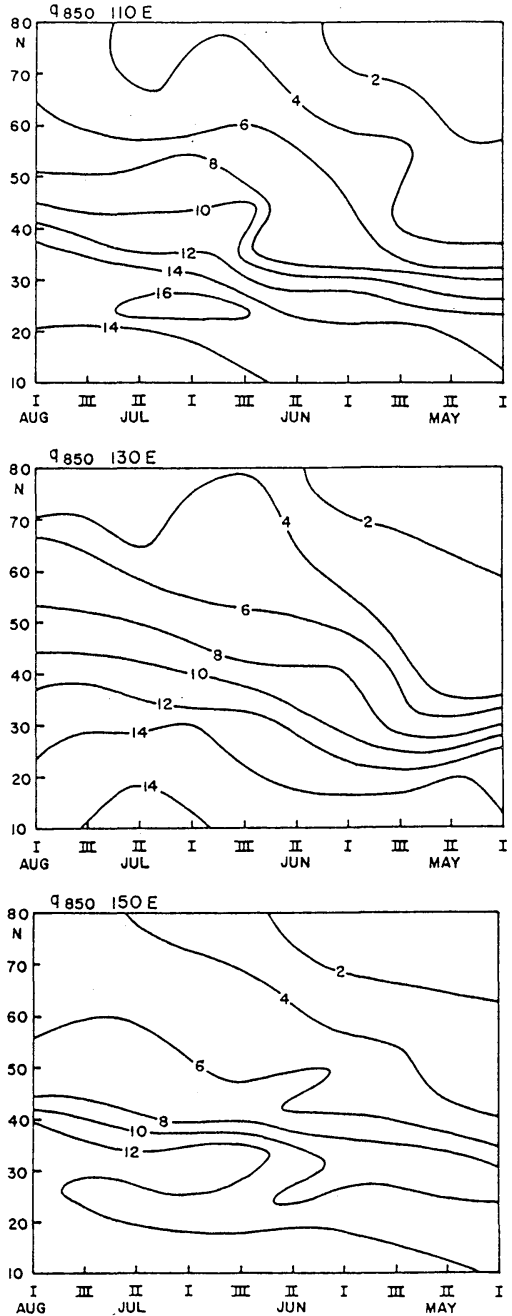

Fig. 15 The latitude-time section of 10-day averaged $850 \mathrm{mb}$ specific humidity $\left(q_{850}\right)$ along 110,113 and $150^{\circ} \mathrm{E}$ meridian.

This maximum zone shifted northward with the seasonal northward advancement of the Pacific anticyclone. The moisture convergence in the Meiyu front was seen along the northern boundary of the area of southerly moisture flux, while that in the Baiu front was seen along the northern boundary of the area of southwesterly moisture flux.

A large seasonal change of $\boldsymbol{V} \boldsymbol{q}$ was observed over India. The flux was small in May. Around Jun I, with the development of the low-pressure area to the south of the Tibetan Plateau, the moisture flux in the cyclonic flow around $20^{\circ} \mathrm{N}$ over India, the Bay of Bengal and Indo-China areas intensified.

Around the onset of monsoon and the peak period of Meiyu/Baiu precipitation (Jun III), the moisture flux increased rapidly over India. The zone of maximum $\boldsymbol{V} \boldsymbol{q}$ over India $(2015 \mathrm{~N})$ extended eastward to the Bay of Bengal, IndoChina and farther to ITCZ over the South China Sea. At the same time, the southerly $V \boldsymbol{q}$ from the South China Sea to South China increased.

In the post-Baiu period (and the break monsoon period), the moisture flux decreased rapidly over India, the Bay of Bengal, the South China Sea and South China.

\section{Intraseasonal variation of the Pacific anti- cyclone and Baiu front}

The northward advances of the Pacific anticyclone and the Baiu frontal zone (cloud zone) are the basic seasonal change over the East Asia. We also found the distinct intraseasonal variations of these systems superposed on the seasonal change.

The longitude-time section of $Z_{850}$ along $40^{\circ} \mathrm{N}$ (Fig. 5, bottom) indicates quasi-periodic variations of the Pacific anticyclone with an approximate 40-day period. The maximum westward extension of the Pacific anticyclone was seen in Jun II and Jul III, while the eastward retreat in May II and Jul I. In the latitude-time section of $Z_{850}$ along $130^{\circ} \mathrm{E}$ (Fig. 17), the maximum northward advance of the Pacific anticyclone was seen around Jun II and Jul III, and the southward retreat around May III and Jul II.

Fig. 18 is the latitude-time section of 5-day and $2^{\circ}$ Lat $\times 2^{\circ}$ Lon area averaged high-cloud amount $\left(C_{H}\right)$ along the 120 and $140^{\circ}$ E meridians. Note the Baiu cloud zone extending around $35^{\circ} \mathrm{N}$ and the ITCZ cloud zone around $10^{\circ} \mathrm{N}$. These two major cloud zones were separated by the cloudless area over the subsidence are of the Pacific anticyclone.

The periods of maximum ITCZ cloud amount occurred in May I, Jun III and Aug I, while the minimum periods in May II and Jul II. The peaks of ITCZ cloud amount accorded with the peaks of the monsoon precipitation over India (Jun III and Aug I) while the minimam to the monsoon breaks: The north-south displacement of the 

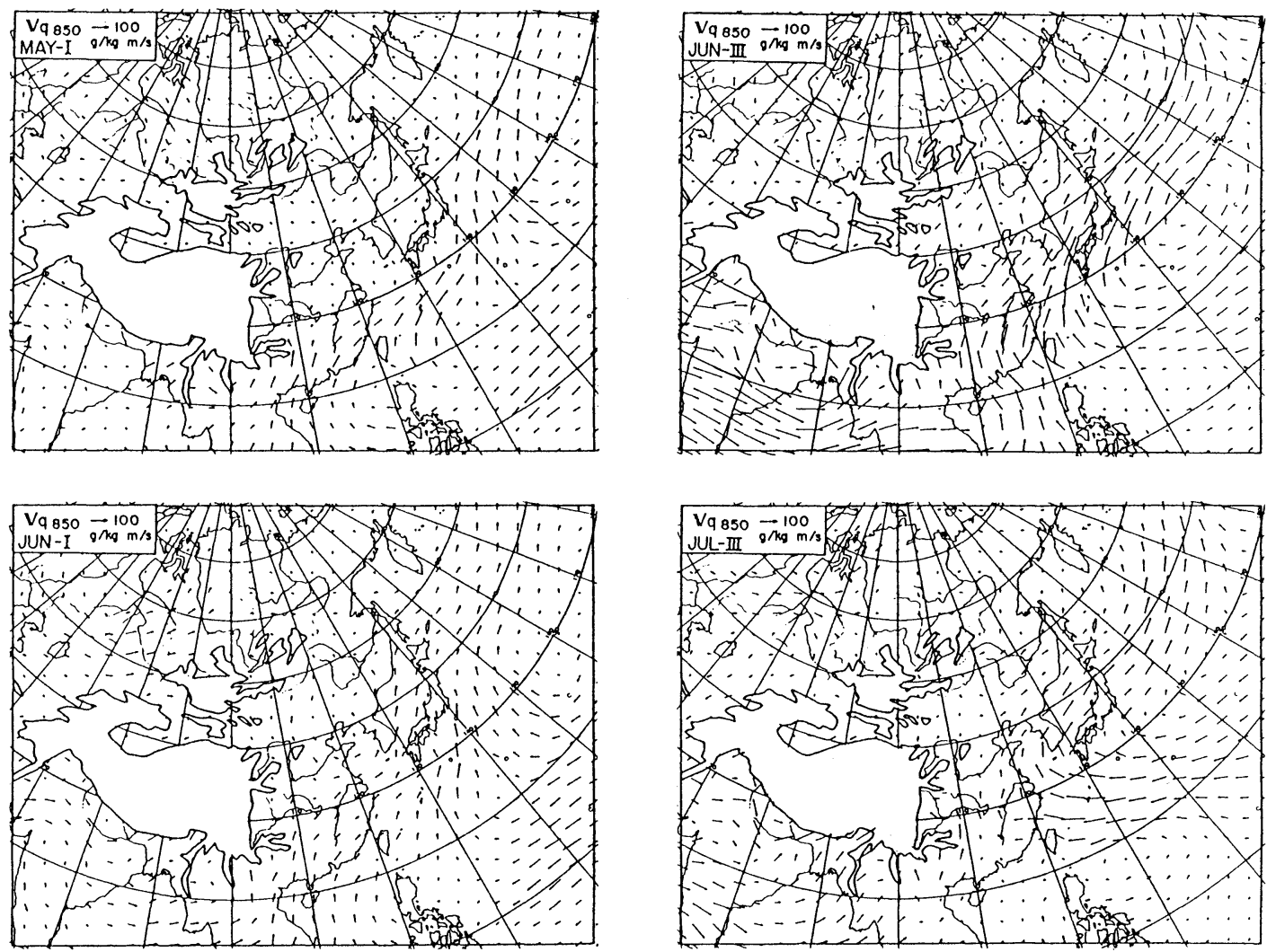

Fig. 16 The 10-day averaged $850 \mathrm{mb}$ water-vapor flux $\left(V q_{850}\right)$ for May I, Jun I, Jun III and Jul III, 1979.

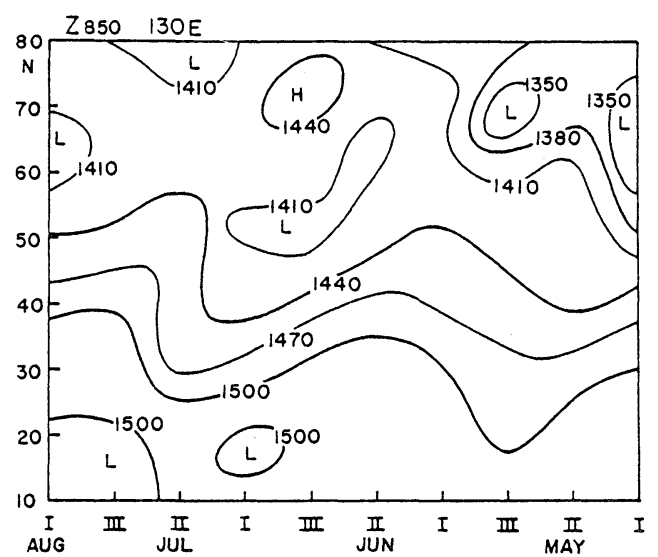

Fig. 17 The latitude-time section of the 10-day averaged $850 \mathrm{mb}$ height $\left(Z_{850}\right)$ along $130^{\circ} \mathrm{E}$ meridian.

cloudless zones (subsidence area of the Pacific anticyclone) and the Baiu frontal cloud zone were related to the convective activity of ITCZ.
The cloudless zone and Baiu cloud zone advanced northward in the peak periods of ITCZ cloud zone (May I, Jun III and Aug I) while retreated southward in the minimum periods of ITCZ cloud cover (May II and Jul II).

The feature along $160^{\circ} \mathrm{E}$ (not presented) was similar to that at $140^{\circ} \mathrm{E}$. On the one hand, the situation along $120^{\circ} \mathrm{E}$ was somewhat complicated, because of the combined effects of the Baiu-trough-northerly winds, monsoon westerly and southeasterly winds in ITCZ on this particular area. The peak of ITCZ cloud cover occurred in Jun II and Aug I, while the maximum of Baiu cloud cover in Jun III and Jul II. These peak periods accorded approximately with these in $140^{\circ} \mathrm{E}$.

We have thus far emphasized the influence of active-break cycle of monsoon on the Baiu front activity through the variations of the ITCZ and the Pacific anticyclone. However, the mechanisms and processes of these influence remain unknown. 

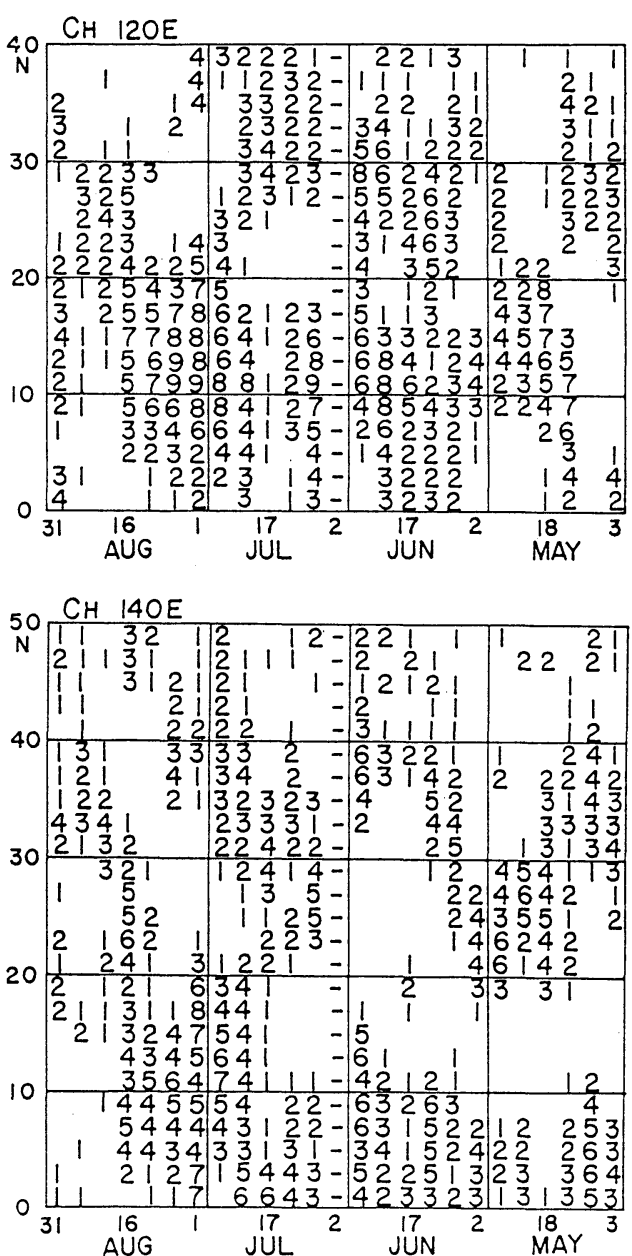

Fig. 18 The latitude-time section of the 5-day averaged high-cloud amount $\left(C_{H}\right)$ along 120 and $140^{\circ} \mathrm{E}$ meridian.

In spite of the prominent intraseasonal variations of the Baiu frontal cloud zone, associated precipitation peaks were not necessarily obvious in the time-series data of precipitation (Fig. 1), except for the prominent precipitation peak in Jun III. It is, then, infered that the intense Baiu precipitation was more closely related with smallscale conditions rather than very large-scale circulations associated with the $\sim 40$-day period oscillations.

\section{Baiu trough, Baiu front and depressions in Baiu season}

In the previous sections, the large-scale circulations in the Baiu season have been described on the basis of 10-day averaged fields. Some description pertaining to individual disturbances, which are superposed on the time-averaged largescale systems, may be necessary. Here, we summarize the features in the 10-day averaged field in the peak period of Baiu (Jun III) and describe the features of individual depressions in relation to the time-averaged field.

Fig. 19 illustrates schematically the large-scale features at $850 \mathrm{mb}$. The axis of Baiu ridge, Baiu trough and the Baiu shear line are illustrated in this figure. The axis of the Baiu-troughnortherly wind, Indian monsoon westerly wind, the South China Sea southerly wind -and SW WSW wind along the periphery of the Pacific anticyclone are indicated by the arrows. Hatching over the Pacific represents regims of large high-cloud amount $\left(C_{H}>0.4\right)$ and that over China indicates regions of intense precipitation exceeding $100 \mathrm{~mm} / 10$ day. (Precipitation area was reproduced from Luo and Yanai, 1983.)

The Meiyu frontal precipitation zone was related with the Baiu shear line. The Baiu frontal cloud zone was located $\sim 1500 \mathrm{~km}$ to the south of the Baiu-trough and along the northwest $~$

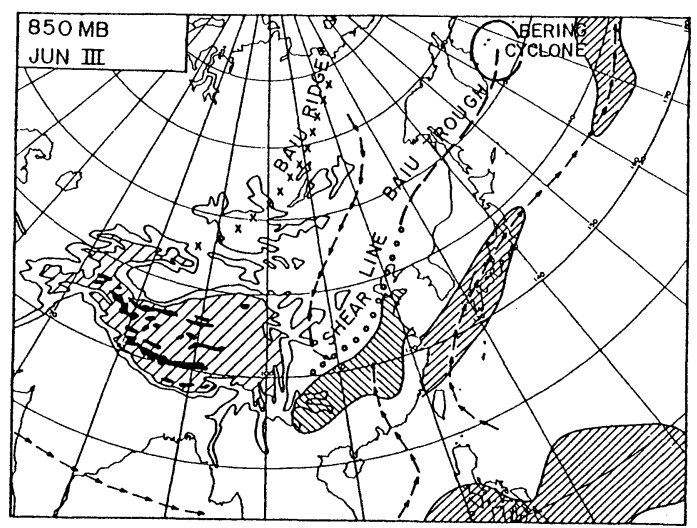

Fig. 19 The schematic illustration of the Baiu ridge, Baiu trough, Baiu shear line and the Bering cyclone at $850 \mathrm{mb}$ for Jun III. The axis of Baiutrough-northerly wind, Indian monsoon westerly wind, the South China Sea southerly wind and SW $\sim$ WSW wind along the periphery of the Pacific anticyclone at $850 \mathrm{mb}$ are indicated by arrows. Hatching over the Pacific indicates the zone of large high-cloud amount $\left(C_{H}>0.4\right)$. Hatching over China indicates area of precipitation exceeding $100 \mathrm{~mm} / 10$ day (reproduced from maps $f$ and $g$ in Fig. 3 of Luo and Yanai, 1983). 
northern periphery of the Pacific anticyclone.

Fig. 20 shows the location of disturbances, which are identified by a closed isobar or height contour, on $700 \mathrm{mb}$ and the surface map at 12 GMT of each day in Jun III. The jet-stream axes on the 10-day averaged $300 \mathrm{mb}$ wind field are indicated by arrows in the top diagram. The disturbances shown in Fig. 20 are classified into the following four categories from their scale, vertical structure and evolution process;

(1) Synoptic-scale disturbances around the polar jet stream (polar frontal disturbances).

(2) Weak disturbances located to the south of the polar jet stream (middle latitude disturbances).

(3) Weak subsynoptic-scale disturbances along the time-averaged Baiu frontal cloud zone
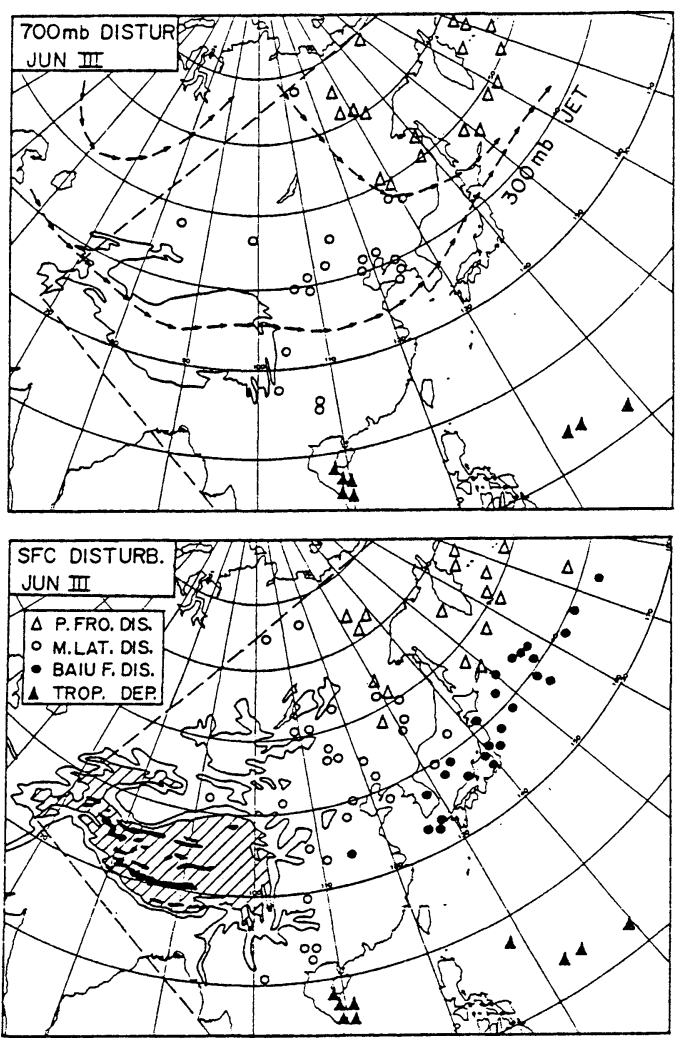

Fig. 20 The locations of $700 \mathrm{mb}$ and the surface disturbances at 12 GMT of each of 10 days within Jun III, 1979. The dashed lines indicate the analyzed domain. The arrows show the jet stream axis on the 10-day averaged $300 \mathrm{mb}$ wind field.
(Baiu frontal disturbances).

(4) Tropical depressions over the Pacific and the South China Sea.

The category-(1) disturbances were associated with the westerly trough in the polar frontal region. Some of them developed into the synopti-scale cyclones over the northwestern Pacific and the Bering Sea. They appeared as a stationary cyclone (the Bering cyclone) on the 10-day averaged field.

The category-(2) disturbances were formed in the north side, or around the eastern foot of the Tibetan Plateau. Usually, they did not developed into deep synoptic-scale cyclone.

The category-(3) disturbances usually develop as subsynoptic-scale (meso- $\alpha$-scale) cloud clusters in satellite cloud images, and do not develop into deep depressions. The cyclonic circulation of these disturbances are not always identified at 850 or $700 \mathrm{mb}$. In spite of the intense precipitation over China, such cloud clusters were not necessarily analyzed as depressions on the conventional synoptic maps. This would be due to the slow deepening of the depression under the condition of very wek baroclinicity in the Meiyu frontal zone. Usually they began to develop into depressions in the area to the east of $130 \sim 135^{\circ} \mathrm{E}$. The cloud systems associated with them appeared as the Baiu frontal cloud zone in the 10-day averaged maps. In this sense, the Baiu front may be regarded as the locus or a train of these subsynoptic-scale depressions. (See Matsumoto et al., 1970; Ninomiya and Akiyama, 1972; Ninomiya et al., 1981; Akiyama, 1978, 1984 for the evolution of Baiu frontal depressions.)

The synoptic situations during the Baiu season vary substantially with time. The situations at a certain synoptic-time were not necessarily the same as these in the time-averaged field. More detailed studies on the relation between the time-averaged large-scale circulation systems and the individual disturbances superposed on the basic flow are necessary in order to understand the physical processes occuring during the Baiu season.

\section{Concluding remarks}

The large-scale aspects of the Baiu/Meiyu 
in 1979 were studied on the basis of 10-day averaged fields. The results are summarized as follows:

(1) The large-scale circulations changed rapidly before, during and after the Baiu season. In the middle and high latitudes, the noteworethy features are the development of a warm ridge (Baiu ridge) over the Mongol $\sim$ Sibirsk Plateaus and a cold trough (Baiu trough) extending from the Bering cyclone to China.

(2) The lower tropospheric circulations suring the Baiu season were characterzied by Baiutrough -north $\sim$ northeasterly winds, southerly winds over the South China Sea and South China, low-level-jet-like strong WSW winds along the periphery of the Pacific anticyclone, and the Indian monsoon westerlies which extended eastward and turned to southerly winds over the South China Sea.

(3) Temperature in the lower troposphere increased rapidly over the Asiatic continent in May $\sim$ June. The temperature gradient over South China decreased and the convective stable condition changed into convectively unstable condition. On the other hand, the temperature increase was less significant over the Pacific north of $35^{\circ} \mathrm{N}$ because of the cold sea surface temperature and cold air advection in the rear of the Bering cyclone. Consequently, a large temperature difference between the Asiatic continent and the Pacific was maintained.

(4) The Tibetan Plateau and the Baiu-troughnortherly-wind prevented the northward intrusion of moist airmass and sustained the strong moisture gradient along the Meiyu frontal zone. Over the Pacific, a strong thermal and moisture gradient in $30 \sim 40^{\circ} \mathrm{N}$ was maintained by the northerly wind in the rear of the Bering cyclone.

(5) While the Meiyu front was related to lowlevel convergence along the Baiu shear line between the Baiu-trough-northerly-winds and the South China Sea southerly winds, the Baiu front was located $\sim 1500 \mathrm{~km}$ south from the Baiu trough and along the northern periphery of the Pacific anticyclone. The convergence in the Baiu frontal zone was associated with confluence of southwesterly winds to the zone of maximum WSW wind.

(6) The Meiyu front and the western part of the Baiu front were characterized by a weak thermal gradient, strong moisture gradient and convectively unstable stratification. Subsynopticscale disturbances in the frontal zone were recognized as subsynoptic-scale cloud clusters. Some of them developed into Baiu frontal depressions in the eastern part of Baiu front where the thermal gradient was relatively large.

(7) The seasonal northward advance of the Pacific anticyclone and Baiu front was the basic seasonal change during the Baiu season. The quasi-periodic $(\sim 40$ day-period) intraseasonal variations were seen superposing on these seasonal changes. In the peak periods of the cloud cover in ITCZ in $120 \sim 160^{\circ} \mathrm{E}$, the Baiu front advanced northward and cloud cover attained maximum value. The peak of Indian monsoon precipitation coinsided approximately with the peak period of ITCZ and Baiu front activity.

(8) During the middle summer, the Pacific anticyclone moved northward, and the Baiu ridge and Baiu trough disappeared. Simultaneously, the geopotential height and temperature patterns changed to zonally symmetric pattern with a weak horizontal gradient.

The results of the present analysis are to be compared with the result of numerical prediction experiments of Baiu by Nakamura, Hasegawa and Ninomiya (1985). They performed 15-day prediction experiment using a global spectral model (12-level, triangular wave number truncation at wave number 42 ) from the initial condition at 12 GMT 15 June 1984. In their experiment, the Baiu front, which was defined as the zone of strong $\nabla \theta_{e}$, was well simulated over China. When the Tibetan Plateau was excluded from the model, the southerly wind prevailed over China associated with the development of cyclones and Baiu front disappeared. This indicates the role of the Tibetan Plateau in the formation of Baiu front.

In the model, the Bering cyclone did not develop and the unrealistic southerly winds prevailed and, thus, low temperature over the Pacific north of $\sim 35^{\circ} \mathrm{N}$ was not maintained and the Baiu front over the Pacific became obscured. This indicates that the Bering cyclone and the associated cold northerly winds over the cool northwestern Pacific is one of the key factors 
for the formation of the eastern half of the Baiu front. These simulation experiments support the inferences in the present observational study that the Tibetan Plateau, the Bering cyclone and the Baiu trough are equally important for the maintenance of the Baiu/Meiyu front.

The Baiu situations vary from one year to another. Ninomiya and Mizuno (1985) described the year-to-year variations of the surface temperature during the Baiu and summer season over Japan for $1951 \sim 1980$. Further studies are needed to compare the features in 1979 with those in other years and identify the common features, besides the year-to-year variations.

\section{Acknowledgement}

This work was made mainly when the authors were in Electronic Computation Center of JMA. The authors acknowledge the discussions with Dr. H. Nakamura and Mr. N. Hasegawa of Numerical Prediction Division, JMA and Dr. T. Akiyama of Meteorological Research Institute. They acknowledge the comments from reviewers in preparing the final paper.

\section{References}

Akiyama, T., 1973: The large-scale aspects of the characteristics features of the Baiu front. Pap. Met. Gephys., 24, 175-188.

- 1978: Mesoscale pulsation of convective rain in medium-scale disturbances developed in Baiu front. J. Met. Soc. Japan, 56, 267-283.

, 1984: A medium-scale cloud cluster in a Baiu front. Part 1; Evolution process and fine structure. J. Met. Soc. Japan, 62, 485-504.

Chen, T.-J.G., and C.-P. Chang, 1980: The structure and vorticity budget of an early summer monsoon trough (Meiyu) over southeastern China and Japan. Mon. Wea. Rev., 108, 942-953.

Kato, K., 1985: On the abrupt change in the structure of the Baiu front over China Continent in late May of 1979. J. Met. Soc. Japan, 63, 20-36.

Krishinamurti, T.N., and D. Subrahmanyam, 1982: The 30 - 50-day mode at $850 \mathrm{mb}$ during MONEX. J. Atmos. Sci., 39, 2088-2095.

Lau, K.-M., and M.-T. Li, 1984: The monsoon of east Asia and its global association. Bull. Amer. Met. Soc., 65, 114-125.

Luo, H.B., and M. Yanai, 1983: The large-scale circulation and heat sources over the Tibetan Plateau and surrounding areas during the early summer of 1979 . Part I: Precipitation and kinematic analysis. Mon. Wea. Rev., 111, 922-944.

Matsumoto, J., 1985: Precipitation distribution and frontal zones over East Asia in the summer of 1979. Bull. Dep. Geography, Univ. Tokyo, No. 17, 45-61.

Matsumoto, S., K. Ninomiya and S. Yoshizumi, 1971: Characteristics features of Baiu front associated with heavy rain. J. Met. Soc. Japan, 49, 267-281.

, S. Yoshizumi and M. Takeuchi, 1970: On the structure of the Baiu front and the associated intermediate-scale disturbances in the lower atmosphere. J. Met. Soc. Japan, 48, 479-491.

Murakami, M., 1984: Analysis of the deep convective activity over the western Pacific Southeast Asia. Part II: Seasonal and interseasonal variation during northern summer. J. Met. Soc. Japan, 62, 88-108. , 1985: On the $30 \sim 50$-day period variations of the atmospheric circulation. Tenki, 32, 459-482. (in Japanese)

Murakami, T., and Y.H. Ding, 1982: Wind and temperature changes over Eurasia during the early summer of 1979. J. Met. Soc. Japan, 60, 183-196.

, and W.-G. Huang, 1984: Orographic effects of the Tibetan Plateau on the rainfall variations over central China during the 1979 summer, J. Met. Soc. Japan, 62, 895-909.

Muraki, H., 1985: Large-scale changes in $300 \mathrm{mb}$ height and $850 \mathrm{mb}$ equivalent potential temperature fields over Asia in and around the Baiu season. Tenki, 32, 585-591. (in Japanese)

Nakamura, H., N. Hasegawa and K. Ninomiya, 1985: A numerical forecast experiment of the large-scale dynamics of Baiu front. Proceeding, International Conference on Monsoon in the Far East, Tokyo, November, 5-8, 1985, 84-89.

Ninomiya, K., 1978: Heavy rainfalls associated with frontal depression in Asian subtropical humid region. J. Met. Soc. Japan, 56, 253-266.

1980: Enhancement of Asian subtropical front due to thermodynamic effect of cumulus convections. J. Met. Soc. Japan, 58, 1-15.

, 1984: Characteristics of Baiu front as a predominant subtropical front in the summer northern hemisphere. J. Met. Soc. Japan, 62, 880894.

Ninomiya, K., and T. Akiyama, 1971: The development of the medium-scale disturbance in the Baiu front. J. Met. Soc. Japan 49, 663-677.

and H. Mizuno, 1985: Anomalously cold spell in summer over northeastern Japan caused by northeasterly wind from polar maritime airmass. Part 1 and 2. J. Met. Soc. Japan, 63, 845-871.

and K. Yamazaki, 1979: Heavy rainfalls associated with frontal depression in Asian subtropical humid region. Part 2. J. Met. Soc. Japan, 57, 399413.

M. Ikawa and T. Akiyama, 1981: Long-lived medium-scale cumulonimbus cluster in Asian subtropical humid region. J. Met. Soc. Japan, 59, 564-577.

, H. Koga, Y. Yamagishi and Y. Tatsumi, 
1984: Prediction experiment of extremely intense rainstorm by a very-fine mesh primitive equation model. J. Met. Soc. Japan, 62, 273-295.

Saito, N., 1985: Quasi-stationary waves in mid-latitudes and the Baiu in Japan. J. Met. Soc. Japan, 63, 983995.

Suginaka, S., 1965: Statistics on Okhotsk Sea anti- cyclones. J. Met. Res., 7, 628-640. (in Japanese)

Takahashi, K., 1969: Synoptic Meteorology. 385pp, Iwanami Press. (in Japanese)

Yoshizumi, S., 1977: On the structure of intermediatescale disturbances on the Baiu front. J. Met. Soc. Japan, 55, 107-120.

\section{9年梅雨期東アジアの大規模場の特徵}

\section{二 宮 洸 三}

(気象庁数值予報課)

\section{村 木 彦 麿}

(東京管区気象台)

1979年梅雨期東アジアの大規模場の特徵と推移を主として10日平均場にもとずいて記述した。従来充 分に解析されていなかった中高緯度の状況にも注目した。

梅雨初期，大規模場は大きく変化する。チベット高原北部から北に伸びる高温リッジ（梅雨リッジ） とベーリング海低気圧から西南西に中国に伸びる低温卜ラフ（梅雨トラフ）が発達する。中国大陸では 下部対流圈の気温が急上昇し，気温傾度は減少し，対流不安定成層となる。一方 $35^{\circ} \mathrm{N}$ 以北の冷い太平 洋ではべーリング海低気圧西方の寒気移流により気温上昇は阻止される。このため著しい大陸〜太平洋 間の気温差が生じる。

対流圈下部の循環は梅雨卜ラフ西側の北東風（梅雨卜ラフ北東風系），太平洋高気圧縁辺の下層ジェ ツト的西南西風系，インドモンスーン西風につらなる南シナ海風系によって特徴づけられる。後者の二 風系は日本列島, 中国域への水蒸気流入をもたらす。

中国の梅雨前線は梅雨卜ラフ北東風と南シ十海南風との間に形成される梅雨シアーラインに密接に関 係する。日本附近の梅雨前線は梅雨トラフの南〜 $1500 \mathrm{~km}$ に位置し, 南西風の西南西強風軸への合流収束 域に位置する。

中国～西日本域の梅雨前線带は水蒸気傾度は大きく気温傾度は弱い。東日本以東では気温傾度もやや 大きい。このため前線帯の中間規模低気圧の発達は〜 $135^{\circ} \mathrm{E}$ 以東でみられる。なおべーリング海域で発 達する低気圧の多くは極前線帯のトラフにともなう低気圧である。

太平洋高気圧と梅雨前線の北上は梅雨期の基本的季節変化である。これに重なって〜40日周期の準周 期的変動がみられる。ITCZ の雲量極大期に梅雨前線が北上し，その雲量・雨量も増加する。特に 6 月 下旬のインドモンスーン降雨の極大期には南シナ海 ITCZの雲量が増加し，梅雨前線活動も増加した。

チベット高原，梅雨卜ラフ北東風は中国～35 $\mathrm{N}$ 以北での低水蒸気量を維持し， ～ $35^{\circ} \mathrm{N}$ 帯に強い水

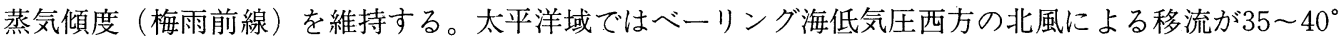
$\mathrm{N}$ に気温傾度と強い水蒸気傾度 (梅雨前線) を保つ。

梅雨末期，太平洋高気圧と上層の高気圧带は北上し，梅雨リッジ，梅雨卜ラフは急速に消失し，高度 場・温度場はゾーナルパタンに変り，傾度は減少し，盛夏となる。

上記のチベット高原，梅雨トラフ，ベーリング海低気圧の梅雨前線生成維持に関する役割についての 推論は，中村・長谷川・二宮 $(1985)$ の予報実験の結果からも支持される。 